\title{
Quantifying nutrient uptake as driver of rock weathering in forest ecosystems by magnesium stable isotopes
}

\author{
David Uhlig ${ }^{1}$, Jan A. Schuessler ${ }^{1}$, Julien Bouchez ${ }^{1, a}$, Jean L. Dixon ${ }^{1, b}$, and Friedhelm von Blanckenburg ${ }^{1,2}$ \\ ${ }^{1}$ GFZ German Research Centre for Geosciences, Earth Surface Geochemistry, Telegrafenberg, 14473 Potsdam, Germany \\ ${ }^{2}$ Institute of Geological Sciences, Freie Universität Berlin, Malteserstr. 74-100, 12249 Berlin, Germany \\ ${ }^{a}$ present address: IPGP-CNRS Institut de Physique du Globe de Paris, Rue Jussieu, 75238 Paris CEDEX 05, France \\ b present address: Department of Earth Sciences, Montana State University, Bozeman, Montana 59717, USA \\ Correspondence to: David Uhlig (david.uhlig@gfz-potsdam.de)
}

Received: 30 November 2016 - Discussion started: 16 January 2017

Revised: 7 May 2017 - Accepted: 14 May 2017 - Published: 26 June 2017

\begin{abstract}
Plants and soil microbiota play an active role in rock weathering and potentially couple weathering at depth with erosion at the soil surface. The nature of this coupling is still unresolved because we lacked means to quantify the passage of chemical elements from rock through higher plants. In a temperate forested landscape characterised by relatively fast $\left(\sim 220 \mathrm{t} \mathrm{km}^{-2} \mathrm{yr}^{-1}\right)$ denudation and a kinetically limited weathering regime of the Southern Sierra Critical Zone Observatory (SSCZO), California, we measured magnesium (Mg) stable isotopes that are sensitive indicators of $\mathrm{Mg}$ utilisation by biota. We find that $\mathrm{Mg}$ is highly bio-utilised: 50 $100 \%$ of the $\mathrm{Mg}$ released by chemical weathering is taken up by forest trees. To estimate the tree uptake of other bioutilised elements ( $\mathrm{K}, \mathrm{Ca}, \mathrm{P}$ and $\mathrm{Si}$ ) we compared the dissolved fluxes of these elements and $\mathrm{Mg}$ in rivers with their solubilisation fluxes from rock (rock dissolution flux minus secondary mineral formation flux). We find a deficit in the dissolved fluxes throughout, which we attribute to the nutrient uptake by forest trees. Therefore both the $\mathrm{Mg}$ isotopes and the flux comparison suggest that a substantial part of the major element weathering flux is consumed by the tree biomass. The enrichment of ${ }^{26} \mathrm{Mg}$ over ${ }^{24} \mathrm{Mg}$ in tree trunks relative to leaves suggests that tree trunks account for a substantial fraction of the net uptake of $\mathrm{Mg}$. This isotopic and elemental compartment separation is prevented from obliteration (which would occur by $\mathrm{Mg}$ redissolution) by two potential effects. Either the mineral nutrients accumulate today in regrowing forest biomass after clear cutting, or they are exported in litter and coarse woody debris (CWD) such that they remain in "solid" biomass. Over pre-forest-management
\end{abstract}

weathering timescales, this removal flux might have been in operation in the form of natural erosion of CWD. Regardless of the removal mechanism, our approach provides entirely novel means towards the direct quantification of biogenic uptake following weathering. We find that $\mathrm{Mg}$ and other nutrients and the plant-beneficial element Si ("bio-elements") are taken up by trees at up to $6 \mathrm{~m}$ depth, and surface recycling of all bio-elements but $\mathrm{P}$ is minimal. Thus, in the watersheds of the SSCZO, the coupling between erosion and weathering might be established by bio-elements that are taken up by trees, are not recycled and are missing in the dissolved river flux due to erosion as CWD and as leaf-derived bio-opal for Si. We suggest that the partitioning of a biogenic weathering flux into eroded plant debris might represent a significant global contribution to element export after weathering in eroding mountain catchments that are characterised by a continuous supply of fresh mineral nutrients.

\section{Introduction}

In continuously eroding landscapes, the mass loss of particles by erosion and solutes by drainage needs to be balanced over a $\sim$ ka timescale by the conversion of rock into regolith, where we define regolith as the entire weathering zone above bedrock, including topsoil. The advance of the weathering front at depth is thus coupled to surface denudation (Brantley and Lebeveda, 2011). It has been hypothesised that biotic processes contribute towards this coupling (Brantley et al., 2011). If the nutrient demand of plants and soil microbes is 
linked to the advance of the weathering front, investigating the dependence of nutrient fluxes on the weathering regime allows for a test of this "biogenic weathering" hypothesis.

The way weathering systems operate can be characterised by two endmembers, each associated with a specific pattern of nutrient dynamics. In the supply-limited regime, the transfer of nutrient-bearing mineral grains from rock into the regolith is so slow that their complete dissolution makes the mineral nutrient status of the regolith very low, such that plants and soil microbes are rather nourished by recycling of nutrients extracted from plant litter (Lang et al., 2016; Vitousek and Farington, 1997) and by atmospheric inputs (Vitousek and Farington, 1997). In the kinetically limited regime, erosion rejuvenates the regolith (Porder et al., 2007), such that the rate of supply outpaces the weathering of minerals (West et al., 2005). In the kinetically limited system, the supply of solutes by chemical weathering into soil solutions ensures that nutrients are readily available for plant uptake from regolith water, and a fraction of these nutrients is lost after bio-utilisation in plant debris such as leaf litter and coarse woody debris (CWD). The plant litter can also be "re-mineralised" (meaning oxidation of plant litter), so that nutrients are lost by drainage in the dissolved form. If erosion of plant debris outpaces nutrient leaching, nutrients are eroded in leaf litter by erosion or stochastically as woody matter in landslides. To replace either loss, nutrients should be uplifted from subsoil layers (Jobbagy and Jackson, 2001; Bullen and Chadwick, 2016). To facilitate the uplift from subsoil in the kinetically limited regime, plants and soil microbes could stimulate chemical weathering rates by decreasing the rhizospheric $\mathrm{pH}$ through respiration and excretion of weathering agents (Brantley et al., 2011). Moreover, the symbiosis of roots with mycorrhiza fungi (Landeweert et al., 2001) could enable plants to directly assimilate nutrients from primary minerals (Jongmans et al., 1997). Here we explore this set of hypotheses in a kinetically limited mountain setting using isotopic and geochemical techniques.

The stable isotopes of magnesium $(\mathrm{Mg})$ - a macronutrient for plants (Marschner, 2011) and a major constituent of the bulk silicate Earth - are suited to trace these cycles. Unless the formation of secondary minerals is significant (Wimpenny et al., 2014), the main shift affecting the ${ }^{26} \mathrm{Mg} /{ }^{24} \mathrm{Mg}$ ratio in weathering systems is the isotopic fractionation towards high ratios during nutrient uptake by plants (Black et al., 2008; Bolou-Bi et al., 2012; Mavromatis et al., 2014), such that the residual dissolved $\mathrm{Mg}$ is shifted towards the complementary low ratio. These two isotopically distinct compartments will remain separated if a fraction of the $\mathrm{Mg}$ accumulates in wood of a regrowing forest after clear cutting or if a fraction of the $\mathrm{Mg}$ is eroded after utilisation and is not released back into solution. In that case the isotope ratio serves as a proxy for the catchment-wide net nutrient uptake flux, where "net" excludes dissolution from biomass and recycling. Here we use an isotope mass balance model (Bouchez et al., 2013) to quantify the relative fluxes of $\mathrm{Mg}$ transfer in the ecosystem after $\mathrm{Mg}$ release by rock weathering: uptake into plants, export as solute or erosion in particles including minerals and a substantial CWD fraction at three forested headwater catchments.

\section{Methods}

\subsection{Study site}

Our study sites comprise three catchments at Providence Creek, Sierra Nevada, USA, and are part of two monitoring programs: Kings River Experimental Watersheds (KREW) and Southern Sierra Critical Zone Observatory (SSCZO). The extensive monitoring dataset is highly suited for nutrient cycling studies in forest ecosystems and provides evidence that rock phosphorus (P) might be growth limiting (Hahm et al., 2014). Our study sites are underlain by granodiorite bedrock (Bateman and Wones, 1972) and mantled by weakly developed soils comprising entisols and inceptisols (Bales et al., 2011). The main vegetation cover is Sierran mixed conifer comprising Pinus ponderosa, Pinus lambertiana, Abies concolor and Libocedrus decurrens (McCorkle et al., 2016).

Soil water and stream water $\mathrm{pH}$ ranges from 5.5 to 7 . We estimate the soil production rate from the total denudation rate from cosmogenic nuclides, which is $\sim 220 \mathrm{t} \mathrm{km}^{-2} \mathrm{yr}^{-1}$ (Dixon et al., 2009). This weathering regime is kinetically limited and soils are only partially depleted in mineral nutrients. Concerning dust inputs, Aciego et al. (2017) recently suggested that $\mathrm{P}$ supply by dust deposition outpaces local bedrock-derived P supply at the SSCZO for ecosystems developed over P-poor bedrock. However, estimates of the influence of dust inputs on nutrient dynamics are minor compared to the total denudation rate at our sites, with inputs of 3 to $36 \mathrm{t} \mathrm{km}^{-2} \mathrm{yr}^{-1}$ (Aciego et al., 2017). Importantly, the total denudation rate of $220 \mathrm{t} \mathrm{km}^{-2} \mathrm{yr}^{-1}$ (Dixon et al., 2009) measured at this site is higher than the range of denudation rates of $103-175 \mathrm{t} \mathrm{km}^{-2} \mathrm{yr}^{-1}$ used in Aciego et al. (2017), and the $\mathrm{P}$ bedrock concentrations are higher in the Providence catchments studied here. We excluded the catchment comprising P-poor bedrock at site D102 (Duff Creek). The ratio of elemental dust deposition to the local, bedrock-derived elemental supply flux (referred to as $\mathrm{RP}^{X}$ in the following) amounts to less than $4 \%$ for $\mathrm{K}, \mathrm{Ca}$ and $\mathrm{Mg}$ and to $5.3 \%$ for $\mathrm{P}$ at our sites and agrees with data shown in Aciego et al. (2017) for the P-rich bedrock. Therefore, the atmospheric supply flux of mineral nutrients can be considered to be insignificant relative to the local long-term supply fluxes from weathering.

\subsection{Analytical methods}

The chemical composition of soil, saprolite and rock samples were analysed by X-ray fluorescence spectrometry (XRF, Panalytical Axios Advanced) on fused tablets at GFZ Potsdam or by Acme Labs, Canada, with uncertainties better than 
$10 \%$ relative. Additional concentration data were compiled from Hahm et al. (2014) and Riebe and Granger (2013). Element concentrations in plant material were analysed by an inductively coupled plasma optical emission spectrometer (ICP-OES, Varian 720ES) with uncertainties better than $15 \%$, after complete dissolution in $\mathrm{HNO}_{3} / \mathrm{H}_{2} \mathrm{O}_{2}$ in PFA vials on a hotplate or using a microwave digestion system as successfully applied in previous $\mathrm{Mg}$ isotope studies (e.g. BolouBi et al., 2012). Dissolved element concentrations in water samples were analysed by ICP-OES following the procedure described in Schuessler et al. (2016), inductively coupled plasma quadrupole mass spectrometry (Q-ICP-MS, Thermo iCAP-Q) and ion chromatography (Thermo Dionex DX-120) with uncertainties better than $10 \%$, respectively. All data of samples and reference materials (for assessment of analytical uncertainties) are reported in Tables S1, S2 and S3a-c in Uhlig et al. (2017).

\subsection{Mg isotope analyses by MC-ICP-MS}

$\mathrm{Mg}$ stable isotope analyses have been performed at GFZ Potsdam, Helmholtz Laboratory for the Geochemistry of the Earth Surface (HELGES). Samples and reference materials were digested in PFA vials using ultra-pure acid mixtures ( $\mathrm{HF}, \mathrm{HCl}, \mathrm{HNO}_{3}, \mathrm{H}_{2} \mathrm{O}_{2}$ ). The exchangeable $\mathrm{Mg}$ fraction of soil and saprolite samples was obtained by a $1 \mathrm{M} \mathrm{NH}_{4} \mathrm{OAc}$ extraction (Arunachalam et al., 1996). This procedure was specifically tested for $\mathrm{Mg}$ isotope measurements (Bolou-Bi et al., 2012). After extraction, the residual solids were analysed after $\mathrm{HF} / \mathrm{HNO}_{3}$ total digestion. Before isotope analysis, $\mathrm{Mg}$ was separated from other matrix elements by column chromatography (AG50W-X12 resin) following the procedure described in Pogge von Strandmann et al. (2011). Matrix elements were eluted with $1 \mathrm{M} \mathrm{HNO}_{3}$, and then $\mathrm{Mg}$ was collected by elution with $2 \mathrm{M} \mathrm{HNO}_{3}$. Purity of the $\mathrm{Mg}$ solutions as well as $\mathrm{Mg}$ yields were verified by analyses of final Mg-containing solutions using ICP-OES or QICP-MS. Mg isotope ratios were measured with a multicollector inductively coupled plasma mass spectrometer (MCICP-MS, Thermo Neptune). All sample solutions were diluted in $0.3 \mathrm{M} \mathrm{HNO}_{3}$, where the sampled $\mathrm{Mg}$ concentration was closely matched to those of the bracketing standard DSM-3. Results are expressed as the \%o difference of the $\mathrm{Mg}$ isotope ratio of the sample relative to the DSM-3 isotope reference material (Galy et al., 2003) using the delta notation: $\delta^{26} \mathrm{Mg}=\left[\left({ }^{26} \mathrm{Mg} /{ }^{24} \mathrm{Mg}\right)_{\text {sample }} /\left({ }^{26} \mathrm{Mg} /{ }^{24} \mathrm{Mg}\right)_{\mathrm{DSM}}-\right.$ $1] \times 1000$. The uncertainty is estimated to be $\pm 0.10 \%$ (2SD) for $\delta^{26} \mathrm{Mg}$, respectively, based on repeat measurements on reference materials (Tables $\mathrm{S} 1, \mathrm{~S} 2, \mathrm{~S} 3 \mathrm{c}$ ).

\subsection{Mg isotope analyses by fsLA-MC-ICP-MS}

The micro-scale $\mathrm{Mg}$ isotope composition of individual minerals (amphibole and biotite) was determined on a thin section of sample BP-0c (from the bedrock-saprolite interface) by UV femtosecond laser ablation coupled to a Thermo Neptune MC-ICP-MS (fsLA-MC-ICP-MS, Fem2) at GFZ Potsdam. Instrumentation, data acquisition and evaluation procedures are described in detail in Schuessler and von Blanckenburg (2014). Laser ablation was performed on individual mineral grains with a spatial resolution of less than $200 \times 200 \mu \mathrm{m}$ surface area with less than $10 \mu \mathrm{m}$ crater depth. The laser beam with a diameter of about $25 \mu \mathrm{m}$ was scanned across the mineral surface to adapt to the irregular shape of the grains and cracks with repetition rates between 13 and $20 \mathrm{~Hz}$. The high-mass-resolution mode of the MC-ICP-MS was used for $\mathrm{Mg}$ isotope ratio measurements. With high mass resolution, isobaric interferences $\left({ }^{52} \mathrm{Cr}^{2+}\right.$ on ${ }^{26} \mathrm{Mg}^{+},{ }^{50} \mathrm{Ti}^{2+}$ and ${ }^{50} \mathrm{Cr}^{2+}$ on ${ }^{25} \mathrm{Mg}^{+}$, or ${ }^{48} \mathrm{Ca}^{2+}$ and ${ }^{48} \mathrm{Ti}^{2+}$ on ${ }^{24} \mathrm{Mg}^{+}$) can be resolved from $\mathrm{Mg}$ isotopes (Dai et al., 2016; Oeser et al., 2014). Mass bias correction was performed using the komatiite glass GOR132-G as bracketing standard. Using a $\delta^{26} \mathrm{Mg}$ value for GOR132-G of $-0.17 \%$ relative to DSM-3 (Oeser et al., 2014), we converted results to $\delta$ values relative to DSM-3. Based on our current experience, we conservatively estimate the uncertainty of the fsLA-MC-ICPMS method for $\mathrm{Mg}$ isotope ratios to be better than $\pm 0.25 \%$ o (2SD) for $\delta^{26} \mathrm{Mg}$. Repeat measurements on reference material BHVO-2G (basaltic glass) (average $\delta^{26} \mathrm{Mg}=-0.07 \pm$ $0.18 \%$, $2 \mathrm{SD}, n=18$ ) agree within uncertainties to published values (Fig. 1) for this reference material $(-0.20 \pm 0.07 \%$; Dai et al., 2016). Results of biotite and amphibole analyses are presented in Fig. 1. Photomicrographs (Fig. 2) show representative analysis locations in amphibole and biotite before and after laser ablation.

\section{Results}

\section{Mg isotopic composition of ecosystem compartments}

The $\mathrm{Mg}$ isotopic composition (Fig. 3, Tables S1, S2, $\mathrm{S} 3 \mathrm{c})$ of mean bulk rock $\left(\delta^{26} \mathrm{Mg}_{\text {rock }}=-0.22 \% \circ \pm 0.10 \%\right.$, 2SD) is identical within uncertainties to mean bulk regolith $\left(\delta^{26} \mathrm{Mg}_{\text {reg }}=-0.15 \% \circ \pm 0.13 \% \circ, 2 \mathrm{SD}\right)$ and mean suspended sediment $\left(\delta^{26} \mathrm{Mg}_{\text {susp.sed }}=-0.30 \% \circ \pm 0.16 \%\right.$, 2SD $)$. Results of analyses on biotite and amphibole on a thin section of rock sample BP-0c indicate that $\mathrm{Mg}$-bearing minerals in the bedrock are not distinguishable in $\delta^{26} \mathrm{Mg}$ within analytical uncertainties and are also identical to the bulk bedrock value of sample BP-0c (Fig. 1). $\delta^{26} \mathrm{Mg}$ in wood from growing trees ranges from -0.21 to $+0.16 \%$, and $\delta^{26} \mathrm{Mg}$ in growing foliage is lower than wood, i.e. -0.72 to $-0.10 \%$. $\delta^{26} \mathrm{Mg}$ of foliage, twigs, bark and needles sampled from the forest floor and from the gauged creek sediment pond is within the range found in living foliage (Fig. 3). The intraplant differences are consistent with previous studies that have shown that during translocation ${ }^{24} \mathrm{Mg}$ is preferred by the foliage whereas ${ }^{26} \mathrm{Mg}$ is preferred by wood (Black et al., 2008; Bolou-Bi et al., 2012). Despite the low $\delta^{26} \mathrm{Mg}$ 

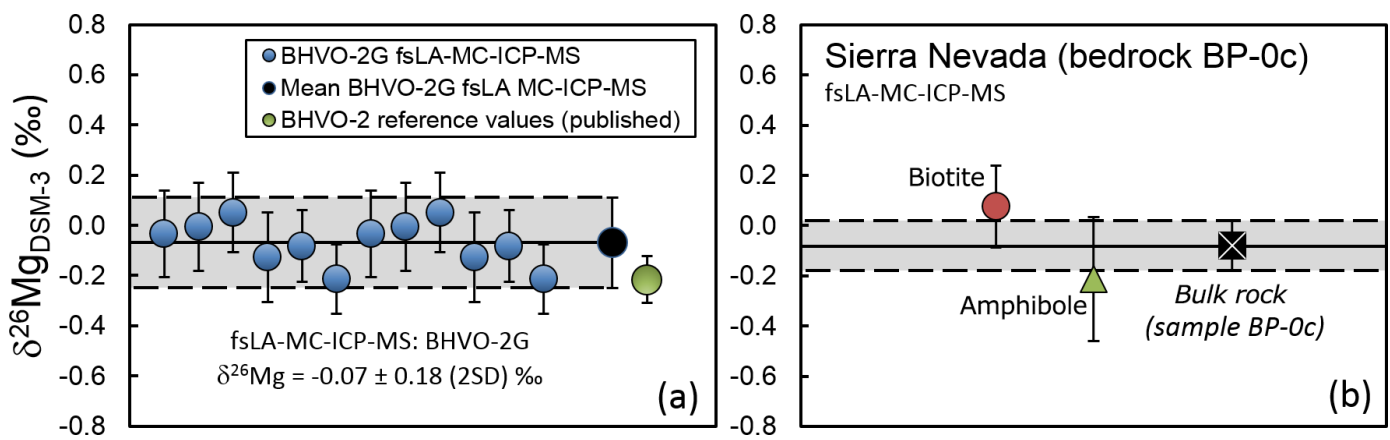

Figure 1. Mg isotopic composition measured by fsLA-MC-ICP-MS. (a) Repeat measurements of BHVO-2G. Solid black circle and solid line represent the mean value of all BHVO-2G measurements with the 2SD range represented by dashed lines. Published literature data (Dai et al., 2016) is shown for comparison. (b) Biotite and amphibole of sample BP-0c measured by fsLA-MC-ICP-MS. Bulk rock was measured by solution MC-ICP-MS.

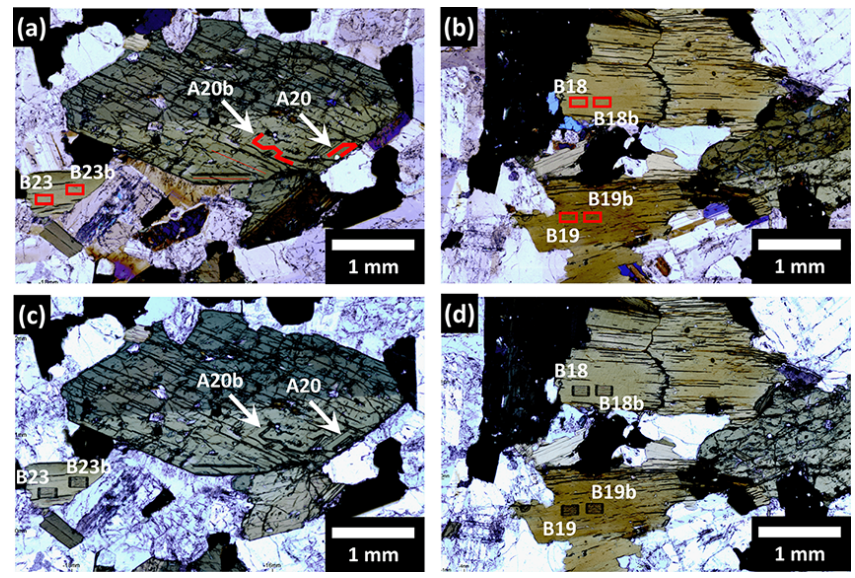

Figure 2. Photomicrographs before and after fsLA-MC-ICP-MS. Red rectangles and lines indicate laser ablation locations. Amphibole before (a) and after (c) fsLA-MC-ICP-MS. Biotite before (b) and after (d) fsLA-MC-ICP-MS.

in foliage, bulk tree $\left(\delta^{26} \mathrm{Mg}_{\text {tree }} \approx-0.07 \%\right.$; see mass balance calculation in Appendix A) is not distinguishable from bulk soil and rock. Only $\mathrm{Mg}$ in creek water $\left(\delta^{26} \mathrm{Mg}_{\text {diss }}=\right.$ $-0.76 \% \circ \pm 0.11 \% o, 2 \mathrm{SD})$ and exchangeable Mg from soil and saprolite $\left(\delta^{26} \mathrm{Mg}_{\text {exch }}=-0.68 \% \circ \pm 0.36 \%\right.$, 2SD $)$ differ from the solid compartments. $\delta^{26} \mathrm{Mg}_{\text {diss }}$ is remarkably constant throughout one hydrological water year and is in the range of global rivers draining silicate catchments (Tipper et al., 2012, and references therein). Results of element concentration measurements in rock, saprolite, soil, vegetation, water and sediment samples are reported together with field measurement data $(\mathrm{pH}$, temperature, conductivity, discharge, alkalinity) in Tables S1, S2, S3a-c.

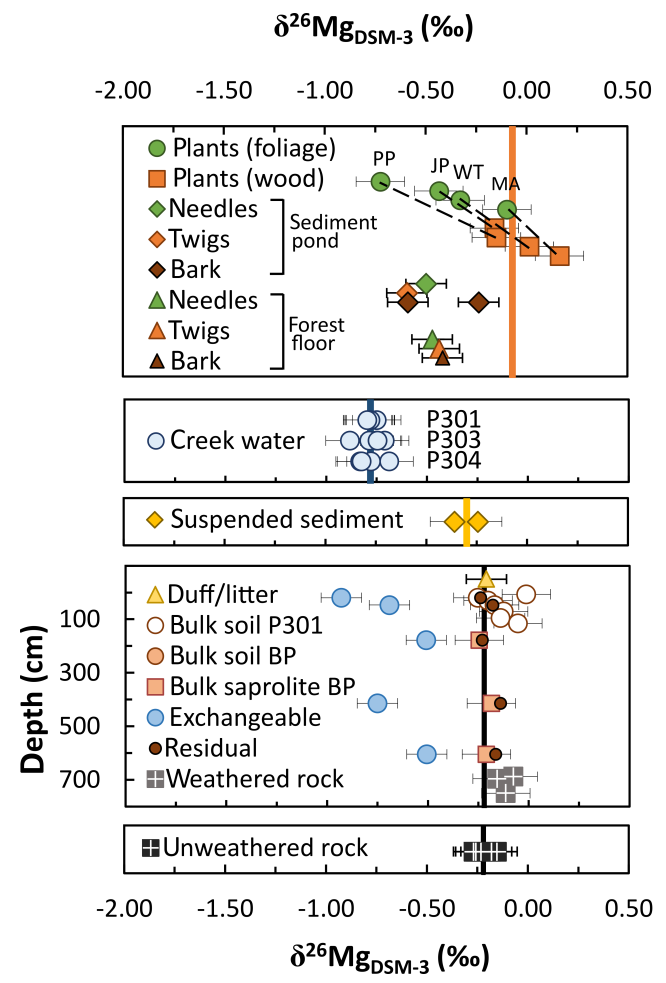

Figure 3. Magnesium isotopic composition of the compartments at Providence Creek, Southern Sierra Nevada, USA. Vertical lines represent mean $\delta^{26} \mathrm{Mg}$ values of bulk unweathered rock (black), bulk suspended sediment (yellow), bulk tree (orange; for mass balance see Appendix A) and creek water (blue). The diagonal dashed lines connect woody with non-woody plant material of the same sample. Exchangeable and residual refer to sequentially extracted soil phases. P301, P303 and P304 refer to headwater catchments at Providence Creek. BP refers to the soil-saprolite profile (balsam profile). PP refers to ponderosa pine (Pinus ponderosa), JP refers to Jeffrey pine (Pinus jeffreyi), WT refers to whitethorn (Ceanothus cordulatus) and MA refers to manzanita (Arctostaphylos manzanita). Error bars amount to $0.10 \%$ (2SD). 


\section{Discussion}

\section{1 $\mathrm{Mg}$ isotope fractionation by clay formation}

Neoformation of $\mathrm{Mg}$ clays is a mechanism that preferentially removes ${ }^{26} \mathrm{Mg}$ from soil solution and enriches this heavy isotope in $\mathrm{Mg}$ clays such as smectite, illite or vermiculite (Wimpenny et al., 2014; Ryu et al., 2016). Clay formation is thus a potential cause for the low $\delta^{26} \mathrm{Mg}_{\text {diss }}$ observed in the Providence Creek streams. Three independent lines of evidence all suggest that this effect is insignificant at our site. First, Mg-clay abundances are beneath the 5\% detection limit of $\mathrm{X}$-ray diffraction (XRD) analysis. Second, their absence was confirmed by thermodynamic modelling (PhreeqC). Third, we use an isotope mass balance based on bulk soil Mg isotope composition to evaluate whether the low $\delta^{26} \mathrm{Mg}$ of dissolved $\mathrm{Mg}$ could nevertheless be due to preferential incorporation of ${ }^{26} \mathrm{Mg}$ into small amounts of $\mathrm{Mg}$ clay. In an isotope mass balance (Eq. 1) we assign $\delta^{26} \mathrm{Mg}_{\text {bulk soil }}$ the value of the isotopically heaviest soil sample $(-0.05 \%$ o, see Table S3c), which has the potential to be most affected by Mgclay formation; for primary minerals $\delta^{26} \mathrm{Mg}_{\text {prim }}$ we use the rock mean $\delta^{26} \mathrm{Mg}_{\text {rock }}(-0.22 \%$, Table S3c).

$$
\begin{aligned}
\delta^{26} \mathrm{Mg}_{\text {bulk soil }}= & \delta^{26} \mathrm{Mg}_{\mathrm{sec}} \times f_{\mathrm{sec}}^{\mathrm{Mg}}+\delta^{26} \mathrm{Mg}_{\text {prim }} \\
& \times\left(1-f_{\mathrm{sec}}^{\mathrm{Mg}}\right)
\end{aligned}
$$

We first solve Eq. (1) for $\delta^{26} \mathrm{Mg}_{\mathrm{sec}}$ with $f_{\mathrm{sec}}^{\mathrm{Mg}}$; the fraction of $\mathrm{Mg}$ borne by secondary minerals is estimated to be $4 \%$, which is contained in an upper possible limit of $5 \% \mathrm{Mg}$ clay (XRD detection limit) relative to $20 \%$ amphibole/biotite in bulk soil (Appendix B). Soil Mg isotopes can only be explained if $\delta^{26} \mathrm{Mg}$ in secondary minerals $\left(\delta^{26} \mathrm{Mg}_{\mathrm{sec}}\right) \geq 4 \%$. To our knowledge, such high clay $\delta^{26} \mathrm{Mg}$ values have never been reported to date (Wimpenny et al., 2014). These clay $\delta^{26} \mathrm{Mg}$ values would require that $\mathrm{Mg}$ clays precipitate from dissolved $\mathrm{Mg}$ with a $\delta^{26} \mathrm{Mg}$ of $\sim 3.5 \%$ o, which has never been observed either (Tipper et al., 2012, and references therein). Second, we solve Eq. (1) for $f_{\mathrm{sec}}^{\mathrm{Mg}}$ by using the maximum published $\delta^{26} \mathrm{Mg}_{\text {sec }}$ of $0.5 \%$ (Ryu et al., 2016 and references therein). This clay value is also consistent with a Rayleigh-type mass balance constrained by the $\delta^{26} \mathrm{Mg}$ of measured stream water and bulk rock as source Mg using $\alpha_{\text {solid-solution }}=1.00054$ (Ryu et al., 2016). In this case the bulk soil Mg-clay content was $30 \%$, far in excess of our XRD analyses (Appendix B).

Therefore, incorporation of $\mathrm{Mg}$ into clays does not drive the low $\delta^{26} \mathrm{Mg}$ of dissolved $\mathrm{Mg}$. The remaining process that depletes soil water in ${ }^{26} \mathrm{Mg}$ is the preferential uptake of ${ }^{26} \mathrm{Mg}$ by plants (Black et al., 2008; Bolou-Bi et al., 2012) associated with an isotope fractionation factor between plant $\mathrm{Mg}$ and dissolved $\mathrm{Mg}$ in the soil solution, expressed as $\Delta^{26} \mathrm{Mg}_{\text {plant-diss }}$.

\subsection{Mg tree uptake fractions from an isotope mass balance}

We quantify the fraction of $\mathrm{Mg}$ uptake by higher plants $\left(f_{\text {uptake }}^{\mathrm{Mg}}\right)$ by an equation frequently used in stable isotope geochemistry (e.g. Black et al., 2008; Johnson et al., 2004) to calculate the partitioning of an element between two distinct compartments (Eq. 2). This equation is derived from a simple "closed system" mass balance model, where the element can freely exchange between the two compartments (which are in turn isolated from any other compartment) and fractionate isotopically between these compartments. $\Delta^{26} \mathrm{Mg}_{\text {plant-diss }}$ is the isotope difference between $\mathrm{Mg}$ in plants and dissolved $\mathrm{Mg}$ in soil water.

$f_{\text {uptake }}^{\mathrm{Mg}}=\frac{\delta^{26} \mathrm{Mg}_{\text {rock }}-\delta^{26} \mathrm{Mg}_{\text {diss }}}{\Delta^{26} \mathrm{Mg}_{\text {plant-diss }}}$

In Eq. (2) we use the isotopic difference between the "initial" $\delta^{26} \mathrm{Mg}_{\text {diss }}$ and $\delta^{26} \mathrm{Mg}_{\text {diss }}$ that has been modified from the initial soil solution by $\mathrm{Mg}$ uptake into plants. Since we do not know the initial $\delta^{26} \mathrm{Mg}_{\text {diss }}$ we use $\delta^{26} \mathrm{Mg}_{\text {rock }}$ as a proxy for this weathering solution, assuming congruent rock dissolution (Bouchez et al., 2013). It can be excluded that differences in primary mineral $\delta^{26} \mathrm{Mg}$ lead to preferential release of specific $\delta^{26} \mathrm{Mg}$, based on fs-laser ablation data of biotite and amphibole, the main Mg carriers, which are similar to $\delta^{26} \mathrm{Mg}$ of bulk bedrock (Sect. 2.4 and Fig. 1). The $f_{\text {uptake }}^{\mathrm{Mg}}$ calculated here presents a minimum estimate ("net") of the total uptake fraction, as it does not include a fraction of $\mathrm{Mg}$ that is potentially recycled back into solution after uptake through $\mathrm{Mg}$ release from plant litter. We note that $f_{\text {uptake }}^{\mathrm{Mg}}$ calculated by Eq. (2) is mathematically equivalent to the results of the steady-state flow-through reactor model of Bouchez et al. (2013) (see below), but here $f_{\text {uptake }}^{\mathrm{Mg}}$ reflects an instantaneous mass balance and does not depend on a steady state of fluxes but applies only to an idealised closed system where plants exchange $\mathrm{Mg}$ with regolith water.

We can also describe both uptake and removal of $\mathrm{Mg}$ by a flow-through reactor isotope model (Bouchez et al., 2013), where the isotope ratios are modelled as a function of elemental fluxes. Combining Eqs. (3c), (3d) and (5e) from Bouchez et al. (2013) and assuming that no $\mathrm{Mg}$ is incorporated into secondary minerals leads to Eqs. (3) and (4):

$$
\begin{aligned}
& \frac{\delta^{26} \mathrm{Mg}_{\text {rock }}-\delta^{26} \mathrm{Mg}_{\text {diss }}}{\Delta^{26} \mathrm{Mg}_{\text {plant-diss }}}=\frac{U^{\mathrm{Mg}}-S_{\text {org }}^{\mathrm{Mg}}}{S_{\text {rock }}^{\mathrm{Mg}}+S_{\text {prim }}^{\mathrm{Mg}}}, \\
& \frac{\delta^{26} \mathrm{Mg}_{\text {rock }}-\delta^{26} \mathrm{Mg}_{\text {diss }}}{\Delta^{26} \mathrm{Mg}_{\text {plant-diss }}}=\frac{E_{\text {org }}^{\mathrm{Mg}}}{S_{\text {rock }}^{\mathrm{Mg}}+S_{\text {prim }}^{\mathrm{Mg}}} .
\end{aligned}
$$

The denominator in the right-hand terms of Eqs. (3) and (4) represents the sum of the Mg supply fluxes from rock dissolution $\left(S_{\text {rock }}^{\mathrm{Mg}}\right)$ at the weathering front and from primary minerals remaining in the regolith $\left(S_{\text {prim }}^{\mathrm{Mg}}\right)$. In Eq. (3) the flux 
term $U^{\mathrm{Mg}}$ quantifies the $\mathrm{Mg}$ uptake flux by trees. $\mathrm{S}_{\text {org }}^{\mathrm{Mg}}$ represents the flux of $\mathrm{Mg}$ from leaching of plant litter that is either recycled back into the plants or discharged into the river. The difference $U^{\mathrm{Mg}}-S_{\text {org }}^{\mathrm{Mg}}$ is therefore the net $\mathrm{Mg}$ accumulation in the "organic" compartment, combining living biomass and plant litter. The use of Eq. (3) does not rely on any steady-state assumption regarding this organic compartment, meaning that the equation applies even if this pool grows, for example during forest growth after deforestation or climate change. If the organic $\mathrm{Mg}$ pool is at steady state, the difference $U^{\mathrm{Mg}}-S_{\text {org }}^{\mathrm{Mg}}$ is equal to $E_{\text {org }}^{\mathrm{Mg}}$, where $E_{\text {org }}^{\mathrm{Mg}}$ refers to the particulate organic Mg export by erosion (Eq. 4). The isotope ratios are thus set by the Mg uptake flux by trees relative to the solubilisation flux of $\mathrm{Mg}$ by chemical weathering. Note that the left-hand term of Eqs. (3) and (4) is identical to the one used for the determination of the relative Mg uptake flux $f_{\text {uptake }}^{\mathrm{Mg}}$ by a closed system mass balance (Eq. 2). As the formation of $\mathrm{Mg}$ clays and the dissolution of carbonates do not affect $\mathrm{Mg}$ fluxes at our study sites (Sect. 4.1, Bateman and Wones, 1972), an isotope difference between rock and dissolved $\mathrm{Mg}$ only emerges if a substantial fraction of isotopically fractionated $\mathrm{Mg}$ accumulates in wood of a regrowing forest after clear cutting or is exported in plant litter or CWD.

To estimate a range for $f_{\text {uptake }}^{\mathrm{Mg}}$ (Eq. 2) or, at steady state, $E_{\text {org }}^{\mathrm{Mg}}$ (Eq. 3), we applied Eqs. (2) and (4) to all individual Providence Creek water samples by using a minimum and maximum $\Delta^{26} \mathrm{Mg}_{\text {plant-diss }}$ of $0.50 \%$ (Opfergelt et al., 2014) and $0.68 \%$ (Black et al., 2008), respectively, and considered the analytical uncertainty on $\delta^{26} \mathrm{Mg}$ of $0.10 \%$ (2SD). The difference of $0.50 \%$ we found between $\delta^{26} \mathrm{Mg}_{\text {diss }}$ and $\delta^{26} \mathrm{Mg}_{\text {rock }}$ shows that 50 to $100 \%$ of the $\mathrm{Mg}$ initially released by chemical weathering is taken up by trees and accumulates in growing forest biomass, or it is eventually eroded in plant litter and CWD. Consequently, because of the high fraction of $\mathrm{Mg}$ uptake, the mean weighted $\delta^{26} \mathrm{Mg}_{\text {tree }}$ is identical to bulk rock (Fig. 3). Therefore, at Providence Creek $\mathrm{Mg}$ is strongly bio-utilised.

$\mathrm{Mg}$ isotopes are unevenly partitioned into the different tree compartments comprising roots, trunk wood and nonwoody foliage. Even though bulk tree $\delta^{26} \mathrm{Mg}$ is higher than $\delta^{26} \mathrm{Mg}_{\text {diss }}$, its composition is close to that of the parent rock and soil (Fig. 3). The reason is that during tree growth, the $\mathrm{Mg}$ taken up is partitioned into a high- $\delta^{26} \mathrm{Mg}$ compartment in woody plant matter and a low- $\delta^{26} \mathrm{Mg}$ compartment in leaves and needles. However, to explain the deficit in ${ }^{26} \mathrm{Mg}$ in dissolved stream $\mathrm{Mg}$, a high- $\delta^{26} \mathrm{Mg}$ compartment has to accumulate in wood or be eroded as plant debris present on the forest floor and then exported as river particulates. We analysed $\delta^{26} \mathrm{Mg}$ of foliage, twigs and bark sampled from the forest floor and a sediment pond containing the erosion products of the ecosystem. Forest floor and sediment pond needles (Fig. 3, Table S2) are isotopically light as expected given that needles become isotopically lighter as they age (Bolou-
Bi et al., 2012). Fine twigs (Fig. 3, Table S2) are isotopically light too. This finding is in contrast with the isotope composition we found in living wood (Fig. 3) and isotopically heavy Mg published for wood (Black et al., 2008; BolouBi et al., 2012). The low $\delta^{26} \mathrm{Mg}$ of the fine twigs (diameter $\sim 3 \mathrm{~mm}$ ) is explained by their $\mathrm{Mg}$ isotopic composition being dominated by bark for which we also found low $\delta^{26} \mathrm{Mg}$ (Fig. 3), consistent with Chapela Lara et al. (2017). Regardless, the compartment containing the required high- $\delta^{26} \mathrm{Mg}$ fraction is not contained in fine plant matter present on the forest floor, making CWD a more likely vector of export for this high- $\delta^{26} \mathrm{Mg}$ component. However, the high- $\delta^{26} \mathrm{Mg}$ fraction is found in the wood of tree trunks (Fig. 3, Table S2). Our isotope mass balance allows for two explanations: transient growth of tree biomass following logging and mechanical removal of tree trunks (Eq. 3); or natural erosion of coarse woody debris (CWD), at steady state with its uptake, with only minor leaching of $\mathrm{Mg}$ (Eq. 4). We return to discussing these mechanisms in Sect. 4.8.

\subsection{Mg weathering fluxes from an isotope mass balance}

The fact that $\mathrm{Mg}$ is highly bio-utilised and most likely eroded as CWD dictates that the dissolved Mg export flux is low relative to other $\mathrm{Mg}$ fluxes in the ecosystem. We use the isotope mass balance model (Bouchez et al., 2013) to calculate the normalised dissolved $\mathrm{Mg}$ export flux ( $w_{\text {isotope }}^{\mathrm{Mg}}$, Table 1) by Eq. (5) and report the data in Table S4b:

$w_{\text {isotope }}^{\mathrm{Mg}}=\frac{\delta_{\text {topsoil }}^{\mathrm{Mg}}-\delta_{\text {rock }}^{\mathrm{Mg}}}{\delta_{\text {topsoil }}^{\mathrm{Mg}}-\delta_{\text {diss }}^{\mathrm{Mg}}}$.

This fraction reflects the $\mathrm{Mg}$ solute export from the whole system relative to the total Mg export of solutes and particulates as primary and secondary minerals plus organic material. Estimating $w_{\text {isotope }}^{\mathrm{Mg}}$ does not depend on knowing isotope fractionation factors, but it assumes a steady state of fluxes.

We use the mean $\delta^{26} \mathrm{Mg}$ of unweathered rock, spatialand time-integrated creek water of the individual Providence Creek sites (P301, P303, P304) and mean bulk soil and saprolite from the P301 soil profile and the soil-saprolite balsam profile (Fig. 3). The mean $\delta^{26} \mathrm{Mg}$ of bulk soil and saprolite was chosen as soil and saprolite samples vary insignificantly in their $\delta^{26} \mathrm{Mg}$ (similar results would be obtained if we had used the topsoil signature only, where topsoil is the compartment that is undergoing erosion at our sites). We consider the isotope composition of this soil-saprolite average to be more representative for exported particulate matter than samples from sediment ponds, because hydrodynamic sorting in the creek channel does not allow representative sampling of sediment from these ponds, where coarse, dense particles are enriched. $\delta^{26} \mathrm{Mg}$ of topsoil, saprolite and bulk rock is identical within their analytical uncertainties. Therefore only a potential upper boundary of the relative $\mathrm{Mg}$ weathering flux 
Table 1. Glossary of symbols.

\begin{tabular}{|c|c|}
\hline \multicolumn{2}{|r|}{ Total mass fluxes (e.g. in $\mathrm{t} \mathrm{km}^{-2} \mathrm{yr}^{-1}$ ) } \\
\hline$D$ & Denudation rate; e.g. the sum of chemical and physical denudation; Eq. (7); Sect. 4.4 \\
\hline \multicolumn{2}{|r|}{ Elemental fluxes $F^{X}$ (e.g. in mol km ${ }^{-2} \mathrm{yr}^{-1}$ ) } \\
\hline $\mathrm{RP}^{X}$ & $\begin{array}{l}\text { Regolith production flux of element } X \text {; transfer of } X \text { from bedrock to regolith at the weathering front; } \\
\text { Eq. (7); Sect. } 4.4\end{array}$ \\
\hline$W_{\text {river }}^{X}$ & Dissolved river flux of element $X$; Eq. (6); Sect. 4.4 \\
\hline$W_{\text {regolith }}^{X}$ & $\begin{array}{l}\text { Net solubilisation flux of element } X \text {; release flux of } X \text { from minerals minus the flux of incorporation of } \\
X \text { into secondary minerals; Eq. (9); Sect. } 4.5\end{array}$ \\
\hline$L^{X}$ & $\begin{array}{l}\text { Litter fall flux of element } X \text {; sum of leaf, trunk and root litter flux of } X \text { from trees to topsoil through } \\
\text { litter fall; Eq. (14); Sect. } 4.7\end{array}$ \\
\hline$E_{\text {org }}^{X}$ & Erosion flux of element $X$ in particulate organic matter or phytoliths; Eq. (4); Sect. 4.2 \\
\hline \multicolumn{2}{|r|}{ Normalised elemental fluxes $f^{X}$} \\
\hline$w_{\text {isotope }}^{X}$ & $\begin{array}{l}\text { Dissolved export flux of element } X \text { relative to the regolith production flux of element } X \text {, calculated } \\
\text { from isotopes; Eq. (5); Sect. } 4.3\end{array}$ \\
\hline$w_{\text {river }}^{X}$ & $\begin{array}{l}\text { Dissolved export flux of element } X \text { relative to the regolith production flux of element } X \text {, calculated } \\
\text { from river loads; } W_{\text {river }}^{X} / \mathrm{RP}^{X} ; \text { Eq. }(8) \text {, Sect. } 4.4\end{array}$ \\
\hline$w_{\text {regolith }}^{X}$ & Normalised net solubilisation flux of element $X ; W_{\text {regolith }}^{X} / \mathrm{RP}^{X} ;$ Eq. (11), Sect. 4.5 \\
\hline $\mathrm{DEE}^{X}$ & Dissolved export efficiency of element $X ; W_{\text {river }}^{X} / W_{\text {regolith }}^{X}$;Eq. (12), Sect. 4.6 \\
\hline $\mathrm{DEE}_{\mathrm{Na}}^{X}$ & Dissolved export efficiency of element $X$; Na-normalised $W_{\text {river }}^{X} / W_{\text {regolith }}^{X}$; Eq. (13), Sect. 4.6 \\
\hline $\operatorname{Rec}^{X}$ & $\begin{array}{l}\text { Nutrient recycling factor; number of passages } X \text { takes through the vegetation after its initial release } \\
\text { from rock; } L^{X} / W_{\text {regolith}}^{X} \text {; Eq. (14), Sect. } 4.7\end{array}$ \\
\hline \multicolumn{2}{|r|}{ Elemental mass fractions } \\
\hline$f_{\mathrm{sec}}^{\mathrm{Mg}}$ & Fraction of Mg carried by secondary minerals relative to total soil Mg; Eq. (1), Sect. 4.1 \\
\hline$f_{\text {uptake }}^{\mathrm{Mg}}$ & Fraction of $\mathrm{Mg}$ taken up by plants relative to $\mathrm{Mg}$ available in soil solution; Eq. (2), Sect. 4.2 \\
\hline & Loss fraction of element $X$; elemental loss or gain relative to unweathered bedrock; Eq. (10); Sect. 4.5 \\
\hline \multicolumn{2}{|r|}{$\mathrm{Mg}$ stable isotope properties (in \%o) } \\
\hline$\delta^{26} \mathrm{Mg}_{\text {comp. }}$ & $\begin{array}{l}\text { Normalised }{ }^{26} \mathrm{Mg} /{ }^{24} \mathrm{Mg} \text { isotope ratio in compartments (e.g. rock, sec, diss, reg, sed, topsoil, plant) } \\
\text { relative to DSM-3 }\end{array}$ \\
\hline$\Delta^{26} \mathrm{Mg}_{\text {plant-diss }}$ & Isotopic difference between $\delta^{26} \mathrm{Mg}_{\text {plants }}$ and $\delta^{26} \mathrm{Mg}_{\text {soil water }}$ \\
\hline
\end{tabular}

$w_{\text {isotope }}^{\mathrm{Mg}}$ can be estimated by propagating the analytical uncertainties as in Bouchez et al. (2013).

Our results show that according to Eq. (5) only $11 \pm 13 \%$ of $\mathrm{Mg}$ is exported from the weathering zone in the dissolved form (Fig. 5). Therefore, the complementary $89 \%$ of $\mathrm{Mg}$ is exported predominantly in primary minerals and in a substantial proportion of CWD.

\subsection{Elemental dissolved river fluxes}

Next, we calculate an independent estimate of the relative dissolved $\mathrm{Mg}$ river flux ( $w_{\text {river }}^{\mathrm{Mg}}$ ) that allows comparison with the isotope-based dissolved $\mathrm{Mg}$ export $\left(w_{\text {isotope }}^{\mathrm{Mg}}\right)$. We also calculate the dissolved river flux $w_{\text {river }}^{X}$ for the macronutrients $(X) \mathrm{K}, \mathrm{Ca}, \mathrm{P}$ and the plant-beneficial element $\mathrm{Si}$ (hereafter we call these elements "bio-elements"). The absolute (nonnormalised) dissolved annual river fluxes for these elements
( $W_{\text {river }}^{X}$, Fig. 4, Table 1) are derived from Eq. (6), which is the sum of the catchment area $(A)$ normalised products of daily dissolved creek water concentrations ( $\left.[X]_{\text {river }_{i}}\right)$ and daily discharge $\left(Q_{i}\right)$ of one hydrological water year:

$W_{\text {river }}^{X}=\sum_{i=1}^{365} \frac{[X]_{\text {river }_{i}} \times Q_{i}}{A}$.

Since we lack daily resolution $[\mathrm{X}]_{\text {river }}$ data and our sampling years (2010-2014) differ from the hydrological water years (2004-2010) for which daily discharge is available (http://criticalzone.org/sierra/data), we use the $[X]_{\text {river- }^{-}}$ $\mathrm{Q}$ linear regression to determine daily $[X]_{\text {river }_{i}}$. We calculate mean discharge values from 15 days before to 15 days after each of our seven $[X]_{\text {river }}$ data points for all hydrological water years 2004-2010 and calculate annual $W_{\text {river }}^{X}$ for the individual hydrological water years 2004-2010 by ap- 


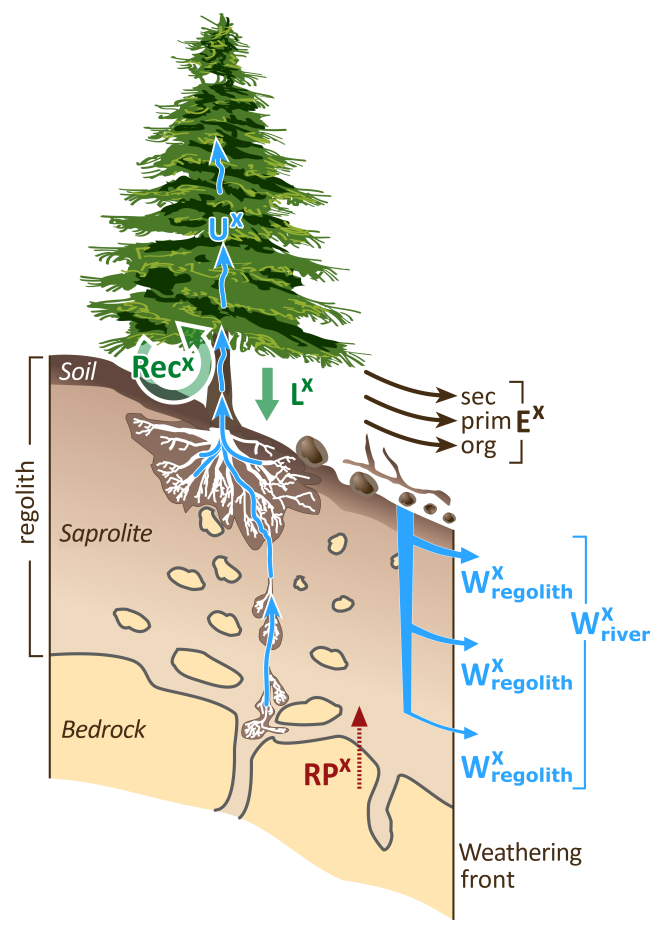

Figure 4. Schematic figure illustrating the metrics used in our flux model. "Org" refers to the sum of coarse woody debris (CWD), litter and trunk wood erosion. $\operatorname{Rec}^{X}$ refers to the nutrient recycling factor of element $X, U^{X}$ refers to the nutrient uptake flux of element $X, L^{X}$ refers to the litter flux of element $X, \mathrm{RP}^{X}$ refers to the regolith production flux of element $X, W_{\text {river }}^{X}$ refers to the dissolved river flux of element $X$ and $W_{\text {regolith }}^{X}$ refers to the net solubilisation flux of element $X$.

plying Eq. (6). We calculate an average of all hydrological water years 2004-2010 to derive $W_{\text {river }}^{X}$ (Table S4a). For example, catchment average $W_{\text {river }}^{\mathrm{Mg}}$ ranges from about 7700 to $28000 \mathrm{~mol} \mathrm{~km}^{-2} \mathrm{yr}^{-1}$.

To allow comparison between flux estimates of different elements, we normalise the measured fluxes using the elemental regolith production rate $\left(\mathrm{RP}^{X}\right.$, Fig. 4, Tables 1, S4a), which quantifies the total transfer of an element $X$ from bedrock to regolith at the weathering front, partitioned into secondary minerals, solutes and remaining primary minerals (Bouchez et al., 2013) by Eq. (7):

$\mathrm{RP}^{X}=D \times[X]_{\mathrm{rock}}$.

Here, we use the total denudation rate $(D$, Table 1$)$ from cosmogenic in situ ${ }^{10} \mathrm{Be}$ concentration from Dixon et al. (2009). Using $D$ of $220 \mathrm{t} \mathrm{km}^{-2} \mathrm{yr}^{-1}$ for all catchments and $[\mathrm{Mg}]_{\text {rock }}$ of 1.9 weight- $\%, \mathrm{RP}^{\mathrm{Mg}}$ is about $175000 \mathrm{~mol} \mathrm{~km}^{-2} \mathrm{yr}^{-1}$. The normalised dissolved river fluxes $\left(w_{\text {river }}^{X}\right)$ are calculated by Eq. (8) (Bouchez et al., 2013) and reported in Table S4b:

$w_{\text {river }}^{X}=\frac{W_{\text {river }}^{X}}{\operatorname{RP}^{X}}$.

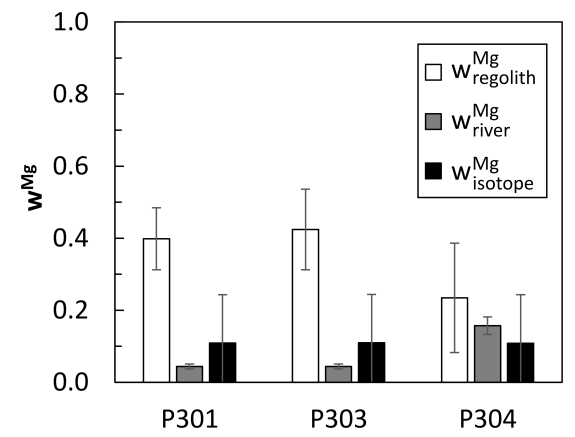

Figure 5. Comparison of the relative weathering flux derived from $\mathrm{Mg}$ isotopes ( $w_{\text {isotope }}^{\mathrm{Mg}}$, Table $\left.\mathrm{S} 4 \mathrm{~b}\right)$, dissolved river loads ( $w_{\text {river }}^{\mathrm{Mg}}$, Table S4b), and net solubilisation fluxes ( $w_{\text {regolith }}^{\mathrm{Mg}}$, Table S4b) for the individual Providence Creek sub-catchments. The ca. 4-fold higher $w_{\text {river }}^{\mathrm{Mg}}$ of the smallest watershed P304 compared to the larger watersheds P301 and P303 might be the result of the relatively high discharge record caused by higher baseflow (Eagan et al., 2007) for such a small watershed. For that reason we consider this catchment to be unrepresentative.

$w_{\text {river }}^{\mathrm{Mg}}$ amounts to $4-16 \%$ (Fig. 5) of $\mathrm{Mg}$ fluxes and is similarly low as $w_{\text {isotope }}^{\mathrm{Mg}}$ of ca. $11 \%$. Thus, in the absence of $\mathrm{Mg}$-containing secondary minerals, $\mathrm{Mg}$ is exported predominantly in remaining primary minerals or, after uptake by plants, in the form of CWD or remains in the wood of a growing forest.

\subsection{Net elemental solubilisation fluxes in the weathering zone}

To test the interpretation that a substantial fraction of $\mathrm{Mg}$ and other bio-elements $(X)$ initially solubilised from rock accumulate in wood (with or without subsequent export as plant litter and CWD), we compare the relative dissolved export fluxes of $\mathrm{Mg} w_{\text {river }}^{\mathrm{Mg}}$ and $w_{\text {isotope }}^{\mathrm{Mg}}$ to the normalised net solubilisation flux ( $w_{\text {regolith }}^{\mathrm{Mg}}$, Table S4b). The non-normalised net solubilisation flux ( $W_{\text {regolith }}^{X}$, Fig. 4, Table 1$)$ is determined by Eq. (9) and reported in Table S4a:

$W_{\text {regolith }}^{X}=\mathrm{RP}^{X} \times\left(-\tau_{\mathrm{Zr}}^{X}\right)$.

$W_{\text {regolith }}^{X}$ is defined as the flux of release of $X$ from minerals undergoing weathering minus the flux of incorporation of $X$ into new minerals potentially formed during weathering reactions (e.g. clays) over the regolith profile. $W_{\text {regolith }}^{X}$ thus quantifies the net release of $X$ from the bedrock-regolith system. $W_{\text {regolith }}^{X}$ is derived from the total denudation rate $(D$, Table 1) bedrock concentrations ([X] $\left.]_{\text {rock }}\right)$ following Eq. (7), combined with mass transfer coefficient (hereafter elemental loss fraction) $\left(\tau^{X}\right.$, Table 1). The loss fraction $\left(\tau^{X}\right)$ quantifies the depletion $\left(\tau^{X}<0\right)$ or enrichment $\left(\tau^{X}>0\right)$ of an element $X$ relative to unweathered bedrock (Anderson et al., 2002; 
Brimhall and Dietrich, 1987). $\tau_{\mathrm{Zr}}^{X}$ is determined by Eq. (10):

$\tau_{\mathrm{Zr}}^{X}=\frac{[\mathrm{Zr}]_{\text {unweathered bedrock }}}{[\mathrm{Zr}]_{\text {weathered regolith }}} \times \frac{[X]_{\text {weathered regolith }}}{[X]_{\text {unweathered bedrock }}}-1$.

$\mathrm{Zr}$ is used as the immobile element. In addition to the dataset of this study, published data (Hahm et al., 2014; Riebe and Granger, 2013) have been used to obtain the most representative bedrock concentrations and are reported with our data in Table S3a-c.

The net solubilisation flux $W_{\text {regolith }}^{X}$ is determined by Eq. (9) for each of the Providence Creek catchments and ranges from 41000 to $75000 \mathrm{~mol} \mathrm{~km}^{-2} \mathrm{yr}^{-1}$ for $\mathrm{Mg}$. Since $\tau_{\mathrm{Zr}}^{X}$ is relatively uniform across the sampled soil-saprolite profile (Fig. 7), mean $\tau_{\mathrm{Zr}}^{X}$ values based on soil and saprolite data from Hahm et al. (2014) and Riebe and Granger (2013) (Table S3) have been used. Only $\tau_{\mathrm{Zr}}^{\mathrm{P}}$ is strongly depth dependent (Fig. 7). Hence we used the most negative $\tau_{\mathrm{Zr}}^{\mathrm{P}}$ from the dataset from Hahm et al. (2014) and Riebe and Granger (2013) (Table S3). The normalised net solubilisation flux $\left(w_{\text {regolith }}^{X}\right)$ is determined by Eq. (11). The comparison to Eqs. (7) and (9) shows that $w_{\text {regolith }}^{X}$ is actually equal to $-\tau_{\mathrm{Zr}}^{X}$ :

$w_{\text {regolith }}^{X}=\frac{W_{\text {regolith }}^{X}}{\mathrm{RP}^{X}}=-\tau_{\mathrm{Zr}}^{X}$.

$w_{\text {regolith }}^{\mathrm{Mg}}$ amounts to $\sim 40 \%$ (Fig. 5), meaning that in the regolith $40 \%$ of the $\mathrm{Mg}$ supplied from rock is transferred into the dissolved form and is made available for plant uptake. Because $w_{\text {regolith }}^{\mathrm{Mg}}$ is much higher than $w_{\text {isotope }}^{\mathrm{Mg}}$ and $w_{\text {river }}^{\mathrm{Mg}}$ (Sect. 4.3 and 4.4), this calculation shows that a substantial fraction of $\mathrm{Mg}$ once released by chemical weathering is taken up into the biomass without subsequent redissolution.

\subsection{Dissolved export efficiency}

To confirm that $\mathrm{Mg}$ is not the only element that is strongly bio-utilised, we compared the dissolved river flux $\left(W_{\text {river }}^{X}\right)$ with the net solubilisation flux $\left(W_{\text {regolith }}^{X}\right)$ by its ratio $W_{\text {river }}^{X} / W_{\text {regolith }}^{X}$ for the other bio-elements (K, Ca, P, Si). Because this ratio quantifies the dissolved riverine loss of $X$ from the ecosystem relative to its net release from the regolith we call the ratio the "dissolved export efficiency" $\left(\mathrm{DEE}^{X}\right.$, Eq. 12, Fig. 6, Table 1):

$\operatorname{DEE}^{X}=\frac{W_{\text {river }}^{X}}{W_{\text {regolith }}^{X}}$.

If the $\mathrm{DEE}^{X}$ is larger than 1 , input sources other than rock weathering are supplying $X$, such as atmospheric deposition (see Sect. 5). The $\mathrm{DEE}^{X}$ is less than 1 if some of the released element is partitioned into a plant uptake flux during forest growth or is eroded as plant litter or CWD (including eroded phytoliths in the case of $\mathrm{Si}$ ). The $\mathrm{DEE}^{X}$ can also differ from

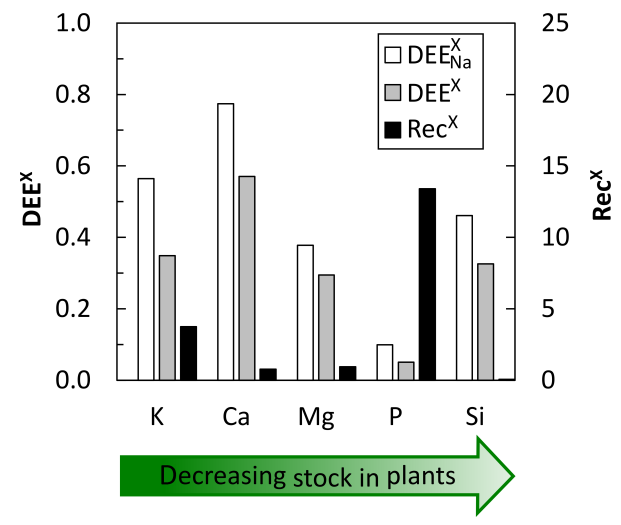

Figure 6. Dissolved export efficiency ( $\mathrm{DEE}^{X}$, left $y$ axis, Table $\mathrm{S} 4 \mathrm{~d}-\mathrm{e})$ and nutrient recycling factor $\left(\operatorname{Rec}^{X}\right.$, right $y$ axis, Table S4f) for macronutrients and the plant-beneficial element Si. The $\mathrm{DEE}^{X}$ quantifies the dissolved riverine loss of $X$ from the ecosystem relative to its net release from the regolith. $\mathrm{DEE}^{X}$ refers to the pure ratio $W_{\text {river }}^{X} / W_{\text {regolith }}^{X}$ (Eq. 12). $\mathrm{DEE}_{\mathrm{Na}}^{X}$ refers to the ratio $W_{\text {river }}^{X} / W_{\text {regolith }}^{X}$ normalised over its corresponding Na fluxes (Eq. 13). $\operatorname{Rec}^{X}$ (Eq. 14) quantifies how often an element $X$ is bioutilised by plants after its release by chemical weathering.

1 , because $W_{\text {river }}^{X}$ and $W_{\text {regolith }}^{X}$ integrate over entirely different timescales.

The inferred $\mathrm{DEE}^{X}(\sim 0.40$ for $\mathrm{K}, \sim 0.60$ for $\mathrm{Ca}, \sim 0.30$ for $\mathrm{Mg}, \sim 0.05$ for $\mathrm{P}$ and $\sim 0.10$ for $\mathrm{Si}$ ) of each nutritive element is less than 1 (Fig. 6), suggesting that some fractions of bio-elements once released by chemical weathering are bio-utilised and remain in regrowing forest biomass after clear cutting or are eventually eroded as CWD. The $\mathrm{DEE}^{X}$ of the non-nutritive element $\mathrm{Na}$ is $<1$ too and amounts to 0.68 (Table S4d). Thus, $\mathrm{DEE}^{\mathrm{Na}}$ suggests that $32 \%$ of $\mathrm{Na}$, which has been released by chemical weathering, is missing in the dissolved river flux. This result is unexpected because $\mathrm{Na}$ behaves conservatively, meaning $\mathrm{Na}$ is neither incorporated into secondary minerals nor taken up as a nutrient by plants. Measured $\mathrm{Na}$ in pine tree wood amounts to 3-8 ppm (Table S2) and in shrub wood to $\sim 40 \mathrm{ppm}$ (Table S2). These low Na contents in plants translate into a plant uptake flux of about $2 \%$ relative to the solubilisation flux, far lower than the $\sim 1 / 3$ of $W_{\text {regolith }}^{\mathrm{Na}}$ estimated from $\mathrm{DEE}^{\mathrm{Na}}$. This observation agrees well with the fact that $\mathrm{Na}$ is only a plant-beneficial element in halophilic and C4/CAM plants (Marschner, 2011) and plays no significant nutritive role in pine trees representing the prevailing plant species at SSCZO. We argue that the supposed deficit in $W_{\text {river }}^{X}$ relative to $W_{\text {regolith }}^{\mathrm{Na}}$ is a timescale effect as $W_{\text {river }}^{X}$ integrates over annual and $W_{\text {regolith }}^{X}$ over millennial timescales.

To obtain a metric that is independent of timescale effects, we normalised the fluxes $W_{\text {river }}^{X}$ and $W_{\text {regolith }}^{X}$ over their respective $\mathrm{Na}$ fluxes (Eq. 13) and rearranged the right-hand term of Eq. (13): 


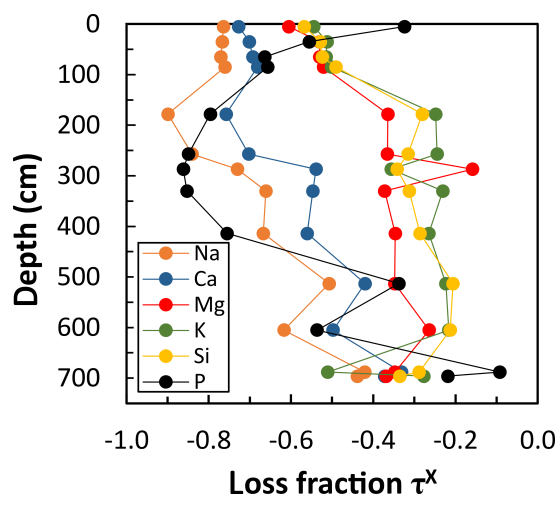

Figure 7. Elemental loss fraction (mass transfer coefficient) $\left(\tau_{\mathrm{Zr}}^{X}\right)$ for macronutrients, the plant essential element $\mathrm{Si}$ and $\mathrm{Na}$ of the soilsaprolite depth profile BP. A $\tau_{\mathrm{Zr}}^{X}$ value $<0$ indicates elemental loss in soil/saprolite relative to unweathered bedrock.

$\mathrm{DEE}_{\mathrm{Na}}^{X}=\frac{\frac{W_{\text {river }}^{X}}{W_{\text {river }}^{\text {Na }}}}{\frac{W_{\text {regolith }}^{X}}{W_{\text {regolith }}^{\text {ago }}}}=\frac{\left(\frac{[X]_{\text {river }}}{[\mathrm{Na}]_{\text {river }}}\right) /\left(\frac{[X]_{\text {rock }}}{[\mathrm{Na}]_{\text {rock }}}\right)}{\frac{\left(\tau_{\mathrm{Zr}}^{X}\right)}{\left(\tau_{\mathrm{Zr}}^{\mathrm{Na}}\right)}}$.

This approach has a fundamental benefit, as knowing the denudation rate $D$ (Eq. 9) from cosmogenic nuclides and the discharge $Q$ (Eq. 6) from long-lasting gauging programs is not required. However, we note that the Na normalisation may also introduce bias into the $\mathrm{DEE}_{\mathrm{Na}}^{X}$ (Table 1). This might be the case if, for example, changes in water flow during the development of the profile over a few thousand years result in a change in the stoichiometry of rock dissolution. Such changes in the congruency in the dissolution of rock might result from changes in the dissolution of Na-bearing primary minerals relative to other primary minerals or from a changing rate of secondary mineral formation relative to Na-bearing primary minerals. In that case the time-integrated denominator in Eq. (13) does not reflect the present value.

The $\mathrm{DEE}_{\mathrm{Na}}^{X}$ values obtained (Fig. 6, Table S4e) show that, of the elements solubilised from rock, $\sim 80 \%$ of $\mathrm{Ca}, \sim 60 \%$ of $\mathrm{K}, \sim 50 \%$ of $\mathrm{Si}, \sim 40 \%$ of $\mathrm{Mg}$ and $\sim 10 \%$ of $\mathrm{P}$ appear in the streams dissolved load. The $\mathrm{DEE}_{\mathrm{Na}}^{X}$ for $\mathrm{Mg}$ is in excellent agreement with the 50-100\% of Mg bio-utilisation calculated independently by isotope mass balances (Eq. 2). The high $\mathrm{DEE}_{\mathrm{Na}}^{X}$ for Ca can be attributed to its high concentrations in rock combined with its high degree of solubilisation by chemical weathering that results in excess availability compared to the nutrient demand of trees. In contrast, the low $\mathrm{DEE}_{\mathrm{Na}}^{X}$ for $\mathrm{P}$ is most likely due to its high biological demand and low availability, resulting in high degree of plant uptake and subsequent export in plant litter and CWD.

\subsection{Nutrient recycling factor}

After uptake and return to the forest floor, nutrients are not directly discharged into the stream by litter dissolution or eroded as plant litter or CWD. Rather, they are subject to recycling - defined here as uptake of nutrients that are made bio-available again after their release from plant litter. The recycling flux can be hypothesised to depend on the ratio of nutrient demand to availability. We thus tested the hypothesis that in our kinetically limited setting, unlike in the supply-limited regime, intense nutrient recycling is not required as nutrient loss can be balanced by supply from mineral dissolution in the regolith (Jobbagy and Jackson, 2001; Lucas, 2001). In other words, if nutrient supply from regolith $\left(W_{\text {regolith }}^{X}\right)$ is high, ecosystem nutrition can be satisfied even if recycling is low (Lang et al., 2016). We quantified nutrient recycling as the number of passages an element $X$ takes through the vegetation after its initial release from rock (quantified by the net solubilisation flux $W_{\text {regolith }}^{X}$ ). We note that the nutrient uptake-release loop is distinct and formally independent of other fluxes such as regolith production, weathering and export fluxes calculated above (Fig. 4). We call the number of passages in the loop the elemental recycling factor $\left(\operatorname{Rec}^{X}\right.$, Fig. 4, Table 1$) . \operatorname{Rec}^{X}$ is determined by Eq. (14) and reported in Table S4f:

$\operatorname{Rec}^{X}=\frac{L^{X}}{W_{\text {regolith }}^{X}}$.

The nutrient uptake flux is the product of net biomass productivity and biomass nutrient concentration ( $U^{X}$, Fig. 4). Since $U^{X}$ is difficult to determine, we use the sum of litter fluxes $\left(L^{X}\right.$; Table 1$)$ comprising foliage litter fall $\left(L_{\text {foliage }}^{X}\right.$, Table S4c), root litter $\left(L_{\text {root }}^{X}\right.$, Table S4c) and trunk litter $\left(L_{\text {trunk }}^{X}\right.$, Table $S 4 \mathrm{c}$ ) instead, assuming balanced uptake and litter fall fluxes (for input parameters see Appendix C). $L^{\mathrm{Mg}}$ is 16000,10000 to 20000 , and $28000 \mathrm{~mol} \mathrm{~km}^{-2} \mathrm{yr}^{-1}$ for foliage, stem and root, respectively. $L^{X}$ represents a minimum estimate for $U^{X}$ and hence $\operatorname{Rec}^{X}$ is likely underestimated because we did not consider return of growth-limiting nutrients from foliage via phloem through roots back into soil during senescence and return of nutrients from throughfall or stem flow.

With an average $\operatorname{Rec}^{\mathrm{P}}$ of $13, \mathrm{P}$ is the only bio-element that is tightly recycled (Fig. 6) and becomes enriched in topsoil (Fig. 7). Aciego et al. (2017) also compared the sum of dust and bedrock-derived $\mathrm{P}$ supply fluxes with nutrient uptake fluxes at SSCZO, obtaining an order of magnitude higher uptake than supply fluxes, and concluded too that $\mathrm{P}$ is recycled. With $\operatorname{Rec}^{K}$ of ca. $4, \mathrm{~K}$ is also recycled. We note that $\operatorname{Rec}^{K}$ is likely underestimated due to the lack of throughfall data, which are generally highest for $\mathrm{K}$ compared to the other bio-elements (Boy and Wilcke, 2008). The $\operatorname{Rec}^{X}$ for the macronutrients $\mathrm{Ca}$ and $\mathrm{Mg}$ is about unity (Fig. 6) and thus these nutrients are not recycled by uptake after release 
from litter. This means that uptake from regolith is their only source. The $\mathrm{Rec}^{\mathrm{Si}}$ of $<0.1$ means that only a minor fraction of Si solubilised from rock is bio-utilised. The low $\operatorname{Rec}^{X}$ values for all bio-essential elements except $\mathrm{P}$ are in agreement with our observation that after uptake the largest mass fraction of these bio-elements remains in wood or is disposed through export of plant litter and CWD. Altogether, the overall high $\mathrm{DEE}_{\mathrm{Na}}^{X}$ (Sect. 4.6) and low $\operatorname{Rec}^{X}$ are consistent with the kinetically limited weathering regime of Providence Creek in which mineral nutrients are supplied in sufficient demand, the ecosystem is "acquiring" and thus the need for recycling is low (Lang et al., 2016).

Although $\operatorname{Rec}^{X}$ and $\mathrm{DEE}_{\mathrm{Na}}^{X}$ rely on $W_{\text {regolith }}^{X}$ we note that both metrics are independent from each other. This independency arises because ecologic stoichiometry enriches other mineral nutrients in plants than released from mineral dissolution kinetics. Thus an element $X$ can become recycled (meaning uptake of nutrients released from plant litter) many times compared to this element's weathering flux $W_{\text {regolith }}^{X}$. This number of cycles as quantified by $\operatorname{Rec}^{X}$ can vary between 0 and a large number. In contrast, $\mathrm{DEE}_{\mathrm{Na}}^{X}$ quantifies the fraction of an element that is exported in the dissolved river load rather than being contained in plant debris, relative to the fraction of $X$ that was initially solubilised by chemical weathering, and can vary between 0 and 1 unless atmospheric input results in $\mathrm{DEE}_{\mathrm{Na}}^{X}>1$.

\subsection{Accumulation of bio-elements during forest growth or export in coarse woody debris (CWD)?}

In the preceding sections, we have suggested two mechanisms that potentially explain the creek water being enriched in ${ }^{24} \mathrm{Mg}$ and the deficit in the dissolved river export fraction indicated by the $\mathrm{DEE}_{\mathrm{Na}}^{X}$ : (1) bio-utilisation and accumulation of bio-elements in wood of a regrowing forest after clear cutting on centennial timescales or (2) solid export of nutrients in CWD by natural erosion in pre-forest-management times and over weathering (kyr) timescales. Concerning logging, in the late 19th century Pinus ponderosa forests became nearly wholesale clear-cut (Graham and Jain, 2005) and our study sites underwent continuous logging of some form through the 1960s (Carolyn Hunsaker, personal communication, 2017). These logging activities triggered the growth of today's forest at Providence Creek and might have shifted the ecosystem from some quasi-steady state - where elemental input fluxes equal elemental export fluxes, and where plant growth equals plant mortality - into an ecosystem being in a transient state characterised by the build-up of a pool of bio-elements (e.g. Sommer et al., 2013). Concerning natural erosion, trunk wood that is enriched in ${ }^{26} \mathrm{Mg}$ is not contained in the sediment pond we sampled. Yet it is continuously removed from the ecosystem by stochastic events, such as tree turnover after tree death (Roering et al., 2010), wind throw or wildfires - which have been suppressed since the late 19th century after which ash is fast eroded.
To estimate whether tree trunk growth satisfies the elemental and isotopic mass balance we estimated the budgets of bio-elements contained in Pinus ponderosa trunk wood (see Sect. 4.7 and Appendix C). We find that the litter fall fluxes $\left(L^{X}\right.$, Table S4c) that we use to estimate uptake indeed are comparable with the deficit in the elemental dissolved export flux as indicated by $1-\mathrm{DEE}_{\mathrm{Na}}^{X}$ for $\mathrm{Mg}$ and $\mathrm{Ca}$. Both the $\mathrm{P}$ and $\mathrm{K}$ trunk wood fluxes are higher than the deficit in the elemental dissolved export flux. This effect arises for strongly recycled elements, because the uptake flux contains the fraction added by nutrient recycling from the forest floor. However, for $\mathrm{Si} \mathrm{Rec}^{X}$ amounts to $<0.1$ whereas the fraction not accounted for by dissolved loss $\left(1-\mathrm{DEE}_{\mathrm{Na}}^{X}\right)$ is 0.54 . A possible reason is that pine needles can treble in Si concentrations as the needles age (Cornelis et al., 2010) and that Si is bioutilised by shrubs whose leaves dispose phytoliths that are not accounted for in our budget. Thus the Si concentrations used in our calculations might be unrepresentative of those in aged leaf litter (Appendix C) and $\mathrm{Rec}^{\mathrm{Si}}$ might be an underestimate. If true, the $1-\mathrm{DEE}_{\mathrm{Na}}^{X}$ of $\mathrm{Si}$ amounting to $50 \%$ is a better estimate for Si uptake.

Whether natural erosion of bio-elements by CWD is a feasible mechanism depends on whether the erosional timescale out-competes the leaching timescale from CWD. Trunk wood decomposition fluxes have been quantified for $\mathrm{Fa}$ gus grandifolia, Acer saccharum and Betula alleghaniensis. About $25-50 \%$ of Ca, 30-70\% of P, 5-20\% of K, 20-40\% of $\mathrm{Mg}$ (Johnson et al., 2014) and 25-60\% of Si (Clymans et al., 2016) remain in trunk wood after 16 years of decomposition. For comparison, after 2 years of Pinus ponderosa foliage litter decomposition $\sim 90 \%$ of $\mathrm{Ca}, \sim 55 \%$ of $\mathrm{P}, \sim 20 \%$ of $\mathrm{K}$ and $\sim 45 \%$ of $\mathrm{Mg}$ (Klemmedson, 1992) remain in foliage litter. The dissolution half-life of the bioopal in phytoliths at the $\mathrm{pH}$ prevailing at Providence Creek amounts to a few hundred days (Fraysse et al., 2009). Therefore, bio-element leaching (except $\mathrm{Ca}$ ) from foliage outpaces bio-element leaching from wood. Hence, after tree death and after litter fall ( $\mathrm{Si}$ contained in phytoliths and $\mathrm{Ca}$ likely contained in oxalates) erosional removal must occur within this decomposition timescales for CWD to be a feasible mechanism.

Given the lack of information on the pre-logging fluxes and isotope ratios at Providence Creek we have no means to assess whether the natural CWD erosion mechanism has been in operation and caused the deficit in dissolved elemental export rather than forest growth today. We can speculate, however, that one effect has replaced the other with similar impact on fluxes. This is because the natural erosion of mineral nutrients in tree trunks in the form of CWD is ultimately limited by tree growth too. One other study, using stable $\mathrm{Sr}$ isotopes in an unperturbed ecosystem in New Zealand, shows a similar partitioning of $\mathrm{Sr}$ between plants and the river dissolved flux (Andrews et al., 2016). Those data can be interpreted to imply natural erosion of $\mathrm{Sr}$ in plant litter and CWD. The same interpretation is possible for the data from 
the Shale Hills Critical Zone Observatory, where a similar deficit in heavy $\mathrm{Mg}$ isotopes was found in stream and soil water (Ma et al., 2015). In that study the bio-cycling hypothesis was dismissed on the grounds of missing accumulation of $\mathrm{Mg}$ in the organic-rich portions of the soil. The existence of a sub-micron pool enriched in ${ }^{26} \mathrm{Mg}$ was hypothesised instead. However, the Mg data at Shale Hills CZO are compatible with the CWD export hypothesis too.

\subsection{Nutrient uplift from the deep saprolite}

We determined the depth from which these nutrients are uplifted. A first indicator is the depth distribution of loss fractions $\tau^{X}$ (Brantley and Lebedeva, 2011) that allows for the identification of so-called biogenic profiles that are characteristically depleted at depth and become enriched in topsoil, because nutrients are uplifted from depth (Jobbagy and Jackson, 2001; Lucas, 2001; Bullen and Chadwick, 2016). Whereas $\mathrm{P}$ depletion amounts to $85 \%$ at $3 \mathrm{~m}$ depth and increases towards the surface, indicating biogenic uplift of $P$, the loss fractions of $\mathrm{Mg}, \mathrm{K}$ and $\mathrm{Si}$ amount to 20 to $40 \%$ and show uniform depletion along the entire depth of the weathering zone down to $7 \mathrm{~m}$ depth. The traditional view is that this loss is induced by mineral dissolution and removal by infiltrating water (Brantley and Lebedeva, 2011). We can use $\mathrm{Mg}$ isotopes to explore an alternative hypothesis: these bio-elements are taken up by tree roots or associated mycorrhiza fungi (Jongmans et al., 1997; Landeweert et al., 2001; Lucas, 2001) at these deep levels. In the absence of $\mathrm{Mg}$ clays and carbonates the isotopically light composition of the exchangeable fraction throughout the regolith $\left(\delta^{26} \mathrm{Mg}_{\text {exch }}\right.$, Fig. 3) can only be caused by the preferential uptake of heavy $\mathrm{Mg}$ isotopes by trees. We can exclude that the development of such an isotopically light exchangeable $\mathrm{Mg}$ compartment throughout the regolith is due to fractionation during adsorption (Opfergelt et al., 2014) as the associated fractionation factor is close to $0 \%$ (Wimpenny et al., 2014). Also, Bullen and Chadwick (2016) have shown that isotopic fractionation during adsorption onto clay minerals is absent for other bivalent cations. We can also exclude that low $\delta^{26} \mathrm{Mg}_{\text {soil water infiltrates to depth from the surface as }}$ this $\delta^{26} \mathrm{Mg}_{\text {soil water }}$ would be masked by the high $\mathrm{Mg}$ solubilisation flux from primary minerals at the considered depth (Fig. 5). Deep water uptake from down to $6 \mathrm{~m}$ is supported by the rooting depth of Pinus ponderosa, which can reach up to $24 \mathrm{~m}$ (Stone and Kalisz, 1991).

\section{Atmospheric depositional fluxes}

$\mathrm{DEE}_{\mathrm{Na}}^{X}, \operatorname{Rec}^{X}$ and the possible enrichment of nutrients from the deep saprolite to shallow soil might all be affected by external dust deposition. Aciego et al. (2017) recently suggested that $\mathrm{P}$ supply by dust deposition outpaces local bedrock P supply at the SSCZO in P-poor bedrock. We have argued in Sect. 2.1 that this observation does not hold for the P-rich bedrock at our sites nor when applied to the other mineral nutrients when long-term $\mathrm{RP}^{X}$ and $W_{\text {regolith }}^{X}$ are considered. Aciego et al. (2017) also compared dust $P$ inputs to modern $\mathrm{P}$ export from sediment trapping, which averages erosion over the annual to decadal timescales of human observations. However, measurements of modern sediment fluxes in streams are known to systematically underestimate erosion rates (total denudation rate minus chemical weathering rate) due to the episodic nature of sediment transport (Kirchner et al., 2001; Schaller et al., 2001). In addition, P export also occurs as dissolved species, which needs to be taken into account when estimating bedrock-derived $\mathrm{P}$ supply using export fluxes. For example, at SSCZO both the total dissolved river export $W_{\text {river }}^{\mathrm{P}}$ and the total weathering flux $W_{\text {regolith }}^{\mathrm{P}}$ that is calculated from cosmogenic nuclides, chemical depletion of regolith and bedrock $P$ concentration exceed the $\mathrm{P}$ erosion flux from sediment trapping by 1 to 2 orders of magnitude. Because at these sites at most $58 \%$ of regolith production is partitioned into a dissolved flux (Dixon et al., 2009), the high recent dissolved flux needs to be associated with a complementary erosion flux. That this is not the case provides further evidence that the erosion flux determined by sediment trapping is a serious underestimate. Therefore from comparing our results with those of Aciego et al. (2017) we suggest that while dust input of $\mathrm{P}$ might be of significance to the local ecosystem on low-P substrate at SSCZO, it is insignificant for $\mathrm{P}$ and the other nutritive elements at our P-rich sites in the Providence Creek catchments.

\section{Implications}

To date the possible acceleration of weathering by plants has only been inferred indirectly by comparing the flux of watersheds of different vegetation cover over short timescales (Moulton et al., 2000). At Providence Creek a substantial fraction of bio-elements released by rock dissolution over typical weathering timescales (thousands of years) is directly utilised by the local forest trees - where nutrient uptake does not depend on the mechanism of export. Our data provide new insight into the role of biota in contributing to weathering fluxes in a given ecosystem. The partitioning of $\mathrm{Sr}$ stable isotopes in a mountain catchment in New Zealand (Andrews et al., 2016) can be interpreted in the same way. It is essential to both metal isotope-based observations that the elements taken up by plants are directly exported as particulate organic material. The low recycling factors observed support this notion of rapid nutrient uptake and disposal. Therefore, in this kinetically limited setting, this mechanism provides a possible tight coupling between weathering up to $6 \mathrm{~m}$ depth and nutrient utilisation and erosion. We do not know whether this deep nutrient uptake is actively driven by nutrient demand (Brantley et al., 2011; Landeweert et al., 2001; Lucas, 2001) or is coupled to deep water uptake during summer droughts. 
Regardless, either cause would deepen the weathering advance front and potentially facilitates the balance between erosion and weathering advance rate.

Considering that $30 \%$ of the Earth's surface is covered by forests (Bonan, 2008) the export of the bio-utilised elements in CWD and bio-opal might represent a more widespread phenomenon. Indeed, in active mountain belts the weathering intensity (total chemical weathering rate normalised by denudation rate) derived from river loads is far lower than that derived from regolith (Dixon and von Blanckenburg, 2012). We suggest that one possible explanation for this discrepancy is the nutrient uptake by biota and its subsequent erosion as bio-opal, leaf litter and CWD in these predominantly kinetically limited weathering regimes. In contrast, in lowland supply-limited regimes and floodplains the low bioelement concentrations in plant debris, the low particulate organic matter sediment yield (0.1-1\% of total sediment yield) (Galy et al., 2015; Hilton, 2017) and the low amorphous opal flux (0.6\% of total sediment yield) (Frings et al., 2016) result in nutrient export to occur predominantly in the dissolved form. The postulated fast weathering and rapid nutrient erosion coupling is significant only in geologically active mountains where CWD and bio-opal erosion are high (Galy et al., 2015; McCorkle et al., 2016), outpace nutrient recycling and might constitute a significant solid export flux of elements released by weathering and hence not accounted for in weathering flux estimates based on dissolved river loads.

\section{Conclusions}

The Mg isotope composition of stream water in the Providence Creek watershed, Southern Sierra Nevada, requires a compartment separation between isotopically light $\mathrm{Mg}$ dissolved in water and isotopically heavy $\mathrm{Mg}$ accumulated in wood of a regrowing forest after clear cutting, or exported in tree wood, without substantial re-mineralisation and reutilisation. A steady-state isotope mass balance supports the solid $\mathrm{Mg}$ export path in that the $\mathrm{Mg}$ export is dominated by particulates, and only a minor fraction of ca. $11 \%$ of $\mathrm{Mg}$ is exported as solutes. Using $\mathrm{Mg}$ isotopes to quantify uptake, we found that $50-100 \%$ of $\mathrm{Mg}$ that is released from primary minerals is utilised by trees. This high $\mathrm{Mg}$ bio-utilisation is confirmed by a deficit apparent in the Nanormalised dissolved river $\mathrm{Mg}$ export flux when compared to the Na-normalised net $\mathrm{Mg}$ solubilisation flux. The deficit of dissolved $\mathrm{Mg}\left(1-\mathrm{DEE}_{\mathrm{Na}}^{\mathrm{Mg}}\right)$, exported by creeks, amounts to $60 \%$, meaning that $60 \%$ of $\mathrm{Mg}$ is bio-utilised. We find similar deficits $\left(1-\mathrm{DEE}_{\mathrm{Na}}^{X}\right)$ amounting to $\sim 40 \%$ for $\mathrm{K}, \sim 20 \%$ for $\mathrm{Ca}, \sim 50 \%$ for $\mathrm{Si}$ and $\sim 90 \%$ for $\mathrm{P}$. These three lines of evidence show that weathering of rock and biogenic uptake are tightly coupled in this fast weathering, kinetically limited regime. In support of this rock-derived nutrient supply scenario we find that no bio-element except $\mathrm{P}$ and $\mathrm{K}$ becomes substantially recycled, i.e. re-mineralised from organic litter and then bio-utilised again. Instead, we infer that $\mathrm{Mg}$, other nutrients and the plant-beneficial element Si accumulate in a forest still growing after clear-cutting up to 50 years ago. As an alternative mechanism likely in operation in pre-forest-management times we suggest that bioutilised elements were disposed from the forest ecosystem in CWD and Si in phytoliths eroded with leaf litter. CWD has potentially been eroded following tree death after wind throw or as ash after wildfires. We find that $\mathrm{Mg}$ is taken up from trees along the entire depth of the weathering profile down to $6 \mathrm{~m}$ depth as indicated by the light $\mathrm{Mg}$ isotopic composition of the easily exchangeable soil fraction. Therefore we provide entirely novel explanations of how biota actively affects weathering fluxes. We suggest that in this kinetically limited regime weathering is tightly coupled to rapid nutrient utilisation and erosion. Finally, we speculate that rapid nutrient erosion might be coupled to fast weathering globally. This coupling then is significant in geologically active mountains where CWD and bio-opal erosion is high and might present a hitherto underestimated solid export flux of elements previously released by chemical weathering.

Data availability. All data used in this study are available as a supplementary dataset in Uhlig et al. (2017), containing the tables S1S4. 


\section{Appendix A: Calculating $\delta^{26} \mathrm{Mg}$ in bulk tree}

We calculate the $\mathrm{Mg}$ isotopic composition of bulk tree $\left(\delta^{26} \mathrm{Mg}_{\text {tree }}\right)$ by a mass balance comprising the aboveground (needles, branches, stem) and belowground (roots) tree compartments. We measured $\delta^{26} \mathrm{Mg}$ in foliage and stem wood. To estimate the isotopic composition of bulk Pinus ponderosa and Pinus jeffreyi we combine these results with $\delta^{26} \mathrm{Mg}$ and $\mathrm{Mg}$ concentration from Bolou-Bi et al. (2012) and the biomass of different compartments of Pinus ponderosa from (Laclau, 2003). We did not measure $\delta^{26} \mathrm{Mg}$ in roots because of the challenges related to their purification from soil particles. Instead we use the published difference between $\delta^{26} \mathrm{Mg}$ in roots and $\delta^{26} \mathrm{Mg}$ in wood (Bolou-Bi et al., 2012) to infer $\delta^{26} \mathrm{Mg}$ in roots from our measured value in wood. The isotopic composition of bulk tree is finally calculated by Eq. (A1), where $f_{\text {compartment }}^{\mathrm{Mg}}$ is the fraction of $\mathrm{Mg}$ in a given tree compartment.

$$
\begin{aligned}
\delta^{26} \mathrm{Mg}_{\text {bulk tree }}= & f_{\text {needle }}^{\mathrm{Mg}} \times \delta^{26} \mathrm{Mg}_{\text {needle }}+f_{\text {stem }}^{\mathrm{Mg}} \\
& \times \delta^{26} \mathrm{Mg}_{\text {stem }}+f_{\text {root }}^{\mathrm{Mg}} \times \delta^{26} \mathrm{Mg}_{\text {root }}
\end{aligned}
$$

The inferred isotopic composition of roots is $0.43 \%$ ofor $\mathrm{Pi}$ nus ponderosa and $0.34 \%$ or Pinus jeffreyi. The $\delta^{26} \mathrm{Mg}_{\text {tree }}$ plotted in Fig. 3 represents a mean value of bulk Pinus ponderosa and Pinus jeffreyi.

\section{Appendix B: XRD analyses and the potential incorporation of $\mathrm{Mg}$ into secondary minerals}

Powder XRD analyses (Siemens D5000, $\mathrm{Cu}-\mathrm{K} \alpha$ radiation) were performed for mineral identification on selected soil, saprolite and bedrock samples. Figure B1 indicates characteristic reflections for some major and minor minerals. Kaolinite is the only secondary mineral identified. The limit of detection is $5 \%$.

The absence of $\mathrm{Mg}$ clays and the presence of kaolinite was confirmed by published clay contents of less than $10 \%$ in the soils (Dahlgren et al., 1997) and by thermodynamic modelling (PhreeqC). Because kaolinite has a low Mg content $(<0.03 \mathrm{wt} \%$; Wimpenny et al., 2014) and a relatively low adsorption cation exchange capacity (CEC) of $<10 \mathrm{cmol}_{\mathrm{c}} \mathrm{kg}^{-1}$ (Wimpenny et al., 2014) it is unlikely to incorporate $\mathrm{Mg}$ in such amounts that the Mg mass balance in soil is affected. Therefore, neoformation of $\mathrm{Mg}$ clays is not the mechanism that preferentially removes ${ }^{26} \mathrm{Mg}$ from soil solution.

The fraction of $\mathrm{Mg}$ potentially contained in clay $\left(f_{\mathrm{sec}}^{\mathrm{Mg}}\right)$ was calculated from the following mass balance. $f_{\mathrm{sec}}^{\mathrm{Mg}}$ is governed by a mixture between $\mathrm{Mg}$ partitioned into $\mathrm{Mg}$ clays and $\mathrm{Mg}$ partitioned into primary minerals such as biotite and amphibole. While the abundances of Mg clays is at maximum $5 \%$ (XRD limit of detection), primary minerals like biotite and amphibole are identified but not quantified by $\mathrm{XRD}$. Hence, we estimate the relative abundances of bi-

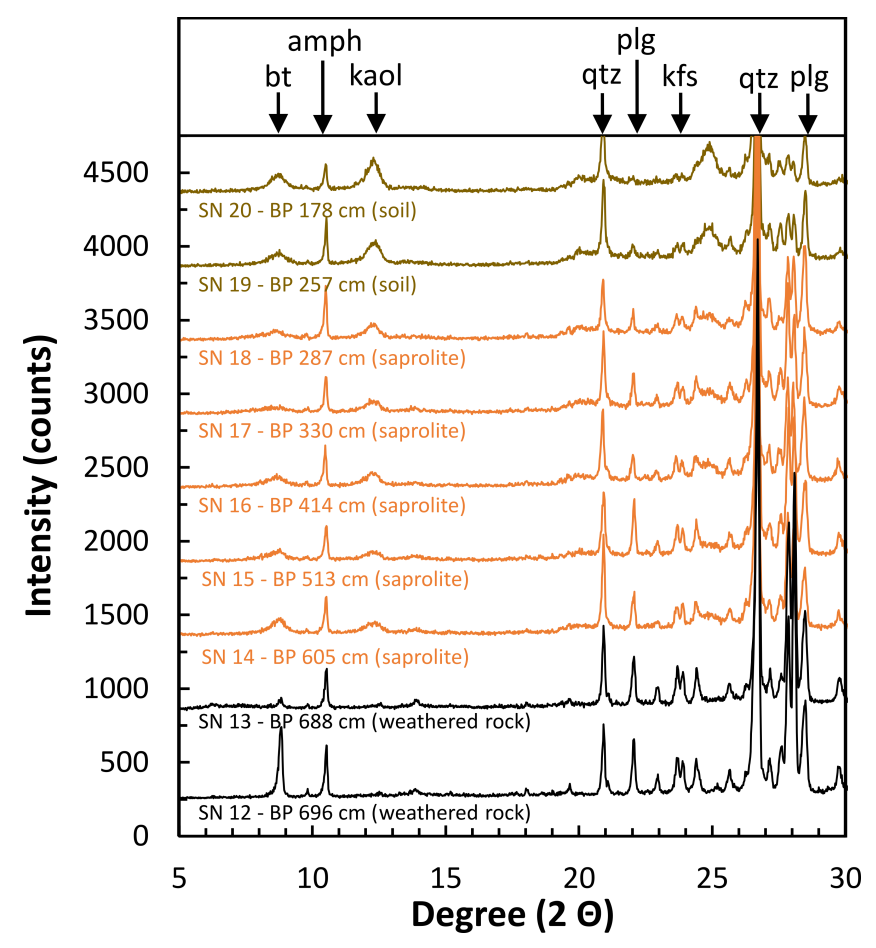

Figure B1. X-ray diffraction (XRD) patterns of bulk soil, bulk saprolite, and bulk bedrock stacked on top of each other. Major reflections of primary minerals $(b t=$ biotite, $a m p h=$ amphibole, $\mathrm{qtz}=$ quartz, $\mathrm{kfs}=\mathrm{K}$-feldspar, $\mathrm{plg}=$ plagioclase) and secondary minerals (kaol $=$ kaolinite) are indicated.

otite and amphibole from bedrock analysis (Bateman and Wones, 1972), which we consider to be applicable to soil too given the kinetically limited weathering regime. We assume all mafic constituents to contain $\mathrm{Mg}$. We use montmorillonite $\left(\mathrm{Al}_{1.67} \mathrm{Mg}_{0.33}\right)\left[(\mathrm{OH})_{2} \mathrm{Si}_{4} \mathrm{O}_{10}\right] \mathrm{Na}_{0.33} \times \mathrm{H}_{2} \mathrm{O}$ (Harder, $1972)$ and biotite $\mathrm{K}(\mathrm{Mg})_{3}\left[(\mathrm{OH}, \mathrm{Fe})_{2}\left(\mathrm{Al}, \mathrm{Fe}, \mathrm{Ti}^{2} \mathrm{Si}_{3} \mathrm{O}_{10}\right]\right.$ as model endmembers for $\mathrm{Mg}$ clays and $\mathrm{Mg}$ carrying primary minerals, respectively. Applying the mineral Mg stoichiometry to the abundances of $\mathrm{Mg}$ clays and biotite reveals that a Mg-clay content of $5 \%$ in the soil translates into $4 \% \mathrm{Mg}$ partitioned into $\mathrm{Mg}$ clays and $96 \% \mathrm{Mg}$ partitioned into biotite. This $4 \%$ is used for $f_{\mathrm{sec}}^{\mathrm{Mg}}$ in Eq. (1), which is solved for $\delta^{26} \mathrm{Mg}_{\text {sec }}$ (see Sect. 4.1).

This calculation confirms that the bulk soil sample with the highest measured $\delta^{26} \mathrm{Mg}(-0.05 \%)$, assuming it contains a maximum allowable Mg-clay content of $5 \%$, can only be explained if $\delta^{26} \mathrm{Mg}_{\mathrm{sec}}$ is $+4.0 \%$, which is highly unlikely (Wimpenny et al., 2014, and references therein). Alternatively, if we use the maximum $\delta^{26} \mathrm{Mg}_{\text {sec }}$ value observed for Mg clay of $0.5 \%$ (Ryu et al., 2016, and references therein) in Eq. (1), then the Mg fraction in the bulk soil carried by $\mathrm{Mg}$ clays $\left(f_{\mathrm{sec}}^{\mathrm{Mg}}\right)$ were $24 \%$. This $24 \% \mathrm{Mg}$ partitioned into $\mathrm{Mg}$ clays can be converted into a $30 \% \mathrm{Mg}$-clay content in the bulk soil, which by far exceeds the XRD detection limit. Such high clay content was not observed by XRD (Fig. B1). 
Finally, we explore whether $\mathrm{Mg}$ isotope fractionation by $\mathrm{Mg}$ adsorption onto kaolinite and amorphous hydroxides might result in the negative $\delta^{26} \mathrm{Mg}_{\text {diss }}$. The evidence for $\mathrm{Mg}$ isotope fractionation during adsorption/desorption is not conclusive and is discussed in Wimpenny et al. (2014) and references therein. Recent experimental evidence suggests that $\mathrm{Mg}$ adsorption is mostly associated with a slightly negative $(-0.1 \%$ ) or complete absence of $\mathrm{Mg}$ isotope fractionation. Thus, our adsorbed $\mathrm{Mg}$ (termed "exchangeable") likely reflects the isotopic composition of the fluid from which the exchange occurred. Indeed our isotopically light exchangeable $\mathrm{Mg}$ isotope analyses is virtually identical to $\delta^{26} \mathrm{Mg}_{\text {diss }}$.

Moreover, for such a process to shift $\delta^{26} \mathrm{Mg}$ in the isotope mass balance (Eq. 1), a substantial amount of $\mathrm{Mg}$ would need to be adsorbed. Our analyses of exchangeable $\mathrm{Mg}$ mass in regolith samples indicate that this compartment makes up less than $0.52 \%$ of the bulk regolith sample (Table S1). This low mass is consistent with the low cation exchange capacity measured in Providence Creek soils (e.g. $\mathrm{Mg}^{2+}<0.45 \mathrm{cmol}_{\mathrm{c}} \mathrm{kg}^{-1}$; Johnson et al., 2011). Hence, neither clay formation nor adsorption is the mechanism that removes isotopically heavy $\mathrm{Mg}$ from soil solutions.

\section{Appendix C: Determining foliage, stem and root litter fall fluxes}

Since litter data for Providence Creek are not available we use total foliage litter fall fluxes of Pinus ponderosa from literature (Grady and Hart, 2006; Klemmedson et al., 1990; Law et al., 1999) and multiply its mean value (see Table S4c) with the elemental foliage litter concentration of Pinus pon- derosa (Klemmedson et al., 1990) to determine $L_{\text {foliage }}^{X}$ for $\mathrm{K}, \mathrm{Ca}, \mathrm{Mg}, \mathrm{P}$ and $\mathrm{Na}$. To determine $L_{\text {foliage }}^{X}$ for $\mathrm{Si}$ we used $L_{\text {foliage }}^{\mathrm{Si}}$ data from Bartoli (1983) and simply converted the units. To determine $L_{\text {root }}^{X}$ we used root litter production data from Röderstein et al. (2005). Since roots were not sampled in this study we used $\mathrm{Mg}, \mathrm{Ca}$ and $\mathrm{K}$ root concentrations from Picea abies (Bolou-Bi et al., 2012), P root concentration from Pinus sylvestris (George et al., 1997) and $\mathrm{Na}$ and $\mathrm{Si}$ needle concentration from Pinus ponderosa from this study. We used Na and Si needle concentration instead its root concentrations as elemental needle and root concentrations are generally similar. Moreover, there is a lack of $\mathrm{Na}$ and $\mathrm{Si}$ root concentrations for coniferous trees in the literature. To determine $L_{\text {trunk }}^{X}$ we estimated the Pinus ponderosa minimum and maximum trunk wood biomass by using a logging calculator (http://www.burleyboys.com, for input parameters see below) and Pinus ponderosa $\mathrm{Mg}, \mathrm{Ca}, \mathrm{K}, \mathrm{Na}$ and $\mathrm{Si}$ wood concentrations from this study and $\mathrm{P}$ wood concentration from Pinus contorta (Pearson et al., 1987).

To estimate a lower limit of Pinus ponderosa trunk wood biomass, we use a diameter at breast height (DBH) of $63 \mathrm{~cm}$ (Law et al., 1999), an upper diameter of $42 \mathrm{~cm}$ (by assuming that the diameter in the crown is reduced by one third compared to the DBH), a tree height of $34 \mathrm{~m}$ (Law et al., 1999) and a stand density of 40000 trees per square kilometre. To convert the trunk wood biomass into an annual growing flux we used a living time of 250 years (Law et al., 1999). To estimate an upper limit of Pinus ponderosa trunk wood biomass we assume a younger forest (200 years) but denser (62 500 trees per square kilometre) forest stand. 
Author contributions. DU analysed samples, interpreted data and wrote text. JS conducted field work, analysed samples, interpreted data and wrote text. JB conducted field work, interpreted data and wrote text. JD conducted field work and provided background information. FvB designed study, conducted field work, interpreted data and wrote text.

Competing interests. The authors declare that they have no conflict of interest.

Acknowledgements. We thank Rudolf Naumann (GFZ) for X-ray diffraction and X-ray fluorescence analyses. Andrea Gottsche (GFZ) is acknowledged for anion quantification using ion chromatography and for assistance in X-ray fluorescence analyses. We also thank Romain Meyer (GFZ) for trace element (P) water analyses by Q-ICP-MS (iCAP-Q). Logistical support and discharge data were provided by the NSF-supported Southern Sierra Critical Zone Observatory: time-series water sampling, sample pre-treatment in the field and shipping were done by Matthew Meadows (University of California, Merced); Carolyn Hunsacker (US Forest Service, Fresno) is thanked for field support and daily Providence Creek discharge data (http://criticalzone.org/sierra/data). We thank Marcus Oelze (GFZ), Friederike Lang (University of Freiburg), Wolfgang Wilcke (KIT, Karlsruhe) and Damien Calmels (UPSud, Orsay) for discussions. David Uhlig and Friedhelm von Blanckenburg are grateful for funding by the German National Science Foundation priority program 1685 "Ecosystem nutrition: forest strategies for limited phosphorus resources".

The article processing charges for this open-access publication were covered by a Research

Centre of the Helmholtz Association.

Edited by: Roland Bol

Reviewed by: two anonymous referees

\section{References}

Aciego, S. M., Riebe, C. S., Hart, S. C., Blakowski, M. A., Carey, C. J., Aarons, S. M., Dove, N. C., Botthoff, J. K., Sims, K. W. W., and Aronson, E. L: Dust outpaces bedrock in nutrient supply to montane forest ecosystems, Nat. Commun., 8, 14800, https://doi.org/10.1038/ncomms14800, 2017.

Anderson, S. P., Dietrich, W. E., and Brimhall, G. H.: Weathering profiles, mass-balance analysis, and rates of solute loss: Linkages between weathering and erosion in a small, steep catchment, Geol. Soc. Am. Bull., 114, 1143-1158, 2002.

Andrews, M. G., Jacobson, A. D., Lehn, G. O., Horton, T. W., and Craw, D.: Radiogenic and stable $\mathrm{Sr}$ isotope ratios $(87 \mathrm{Sr} / 86 \mathrm{Sr}$, $\delta 88 / 86 \mathrm{Sr}$ ) as tracers of riverine cation sources and biogeochemical cycling in the Milford Sound region of Fiordland, New Zealand, Geochim. Cosmochim. Ac., 173, 284-303, 2016.

Arunachalam, J., Emons, H., Krasnodebska, H., and Mohl, C.: Sequential extraction studies on homogenized forest soil samples, Sci. Total Environ., 181, 147-159, 1996.
Bales, R. C., Hopmans, J. W., O'Geen, A. T., Meadows, M., Hartsough, P. C., Kirchner, P., Hunsaker, C. T., and Beaudette, D.: Soil moisture response to snowmelt and rainfall in a Sierra Nevada Mixed-Conifer forest, Vadose Zone J., 10, 786-799, 2011.

Bartoli, F.: The biogeochemical cycle of silicon in two temperate forest ecosystems, Ecol. Bull., 35, 469-476, 1983.

Bateman, P .C. and Wones, D. R.: Huntington Lake Quadrangle, Central Sierra Nevada, California - Analytical Data, Shorter Contributions to General Geology, Geological Survey Professional Paper 724-A, USGS Numbered Series, available at: https://pubs.er.usgs.gov/publication/pp724A (last access: 22 June 2017), 1972.

Brimhall, G. H. and Dietrich, W. E.: Constitutive mass balance relations between chemical composition, volume, density, porosity, and strain in metasomatic hydrochemical systems: results on weathering and pedogenesis, Geochim. Cosmochim. Ac., 51, 567-587, 1987.

Black, J. R., Epstein, E., Rains, W. D., Yin, Q.-Z., and Casey, W. H.: Magnesium-isotope fractionation during plant growth, Environ. Sci. Technol., 42, 7831-7836, 2008.

Bolou-Bi, E. B., Vigier, N., Poszwa, A., Boudot, J. P., and Dambrine, E.: Effects of biogeochemical processes on magnesium isotope variations in a forested catchment in the Vosges Mountains (France), Geochim. Cosmochim. Ac., 87, 341-355, 2012.

Bonan, G. B.: Forests and climate change: forcings, feedbacks, and the climate benefits of forests, Science, 320, 1444-1449, 2008.

Bouchez, J., von Blanckenburg, F., and Schuessler, J. A.: Modelling novel stable isotopes in the weathering zone, Am. J. Sci., 313, 267-308, 2013.

Boy, J. and Wilcke, W.: Tropical Andean forest derives calcium and magnesium from Saharan dust, Global Biogeochem. Cy., 22, GB1027, https://doi.org/10.1029/2007GB002960, 2008.

Brantley, S. L. and Lebedeva, M.: Learning to Read the Chemistry of Regolith to Understand the Critical Zone, Annu. Rev. Earth Pl. Sc., 39, 387-416, 2011.

Brantley, S. L., Megonigal, J. P., Scatena, F. N., Balogh-Brunstad, Z., Barnes, R. T., Bruns, M. A., Van Cappellen, P., Dontsova, K., Hartnett, H. E., Hartshorn, A. S., Heimsath, A., Herndon, E., Jin, L., Keller, C. K., Leake, J. R., McDowell, W. H., Meinzer, F. C., Mozdzer, T. J., Petsch, S., Pett-Ridge, J., Pregitzer, K. S., Raymond, P. A., Riebe, C. S., Shumaker, K., Sutton-Grier, A., Walter, R., and Yoo, K.: Twelve testable hypotheses on the geobiology of weathering, Geobiology, 9, 1-26, 2011.

Bullen, T. and Chadwick, O.: $\mathrm{Ca}, \mathrm{Sr}$ and $\mathrm{Ba}$ stable isotopes reveal the fate of soil nutrients along a tropical climosequence in Hawaii, Chem. Geol., 422, 25-45, 2016.

Chapela Lara, M., Buss, H. L., Pogge von Strandmann, P. A. E., Moore, O. W., and Schuessler, J. A.: The influence of critical zone processes on the $\mathrm{Mg}$ isotope budget in a tropical, highly weathered andesitic catchment, Geochim. Cosmochim. Ac., 202, 77-100, 2017.

Clymans, W., Conley, D. J., Battles, J. J., Frings, P. J., Koppers, M. M., Likens, G. E., and Johnson, C. E.: Silica uptake and release in live and decaying biomass in a northern hardwood forest, Ecology, 97, 3044-3057, 2016. 
Cornelis, J. T., Ranger, J., Iserentant, A., and Delvaux, B.: Tree species impact the terrestrial cycle of silicon through various uptake, Biogeochemistry, 97, 231-245, 2010.

Dahlgren, R. A., Boettinger, J. L., Huntington, G. L., and Amundson, R. G.: Soil development along an elevational transect in the western Sierra Nevada, California, Geoderma, 78, 207-236, 1997.

Dixon, J. L. and von Blanckenburg, F.: Soils as pacemakers and limiters of global silicate weathering, C. R. Geosci., 344, 597609, 2012

Dixon, J. L., Heimsath, A. M., and Amundson, R.: The critical role of climate and saprolite weathering in landscape evolution, Earth Surf. Proc. Land., 34, 1507-1521, 2009.

Eagan, S. M., Hunsaker, C. T., Dolanc, C. R., Lynch, M. E., and Johnson, C. R.: Discharge and Sediment Loads at the Kings River Experimental Forest in the Southern Sierra Nevada of California, in: Advancing the fundamental sciences: proceedings of the Forest Service National Earth Sciences Conference, edited by: Furniss, M., Clifton, C., and Ronnenberg, K., Gen. Tech. Rep. PNW-GTR-689, Forest Service, Pacific Northwest Research Station, 18-22 October 2004, Portland, OR, USA, 217-224, 2007.

Fraysse, F., Pokrovsky, O. S., Schott, J., and Meunier, J.-D.: Surface chemistry and reactivity of plant phytoliths in aqueous solutions, Chem. Geol., 258, 197-206, 2009.

Frings, P. J., Clymans, W., Fontorbe, G., De La Rocha, C. L., and Conley, D. J.: The continental Si cycle and its impact on the ocean Si isotope budget, Chem. Geol., 425, 12-36, 2016.

Galy, A., Yoffe, O., Janney, P. E., Williams, R. W., Cloquet, C., Alard, O., Halicz, L., Wadhwa, M., Hutcheon, I. D., Ramon, E., and Carignan, J.: Magnesium isotope heterogeneity of the isotopic standard SRM980 and new reference materials for magnesium-isotope-ratio measurements, J. Anal. Atom. Spectrom., 18, 1352-1356, 2003.

Galy, V., Peucker-Ehrenbrink, B., and Eglington, T.: Global carbon export from the terrestrial biosphere controlled by erosion, Nature, 521, 204-207, 2015.

George, E., Seith, B., Schaeffer, C., and Marschner, H.: Responses of Picea, Pinus and Pseudotsuga roots to heterogeneous nutrient distribution in soil, Tree Physiol., 17, 39-45, 1997.

Grady, K. C. and Hart, S. C.: Influences of thinning, prescribed burning, and wildfire on soil processes and properties in southwestern ponderosa pine forests: a retrospective study, Forest Ecol. Manag., 234, 123-135, 2006.

Graham, R. T. and Jain, T. B.: Ponderosa pine ecosystems, in: Proceedings of the Symposium on Ponderosa Pine: Issues, Trends, and Management, Gen. Tech. Rep. PSW-GTR-198, Pacific Southwest Research Station, Forest Service, US Department of Agriculture, 18-21 October 2004, Albany, CA, USA, 1-32, 2005.

Hahm, W. J., Riebe, C. S., Lukens, C. E., and Araki, S.: Bedrock composition regulates mountain ecosystems, P. Natl. Acad. Sci. USA, 111, 3338-3343, 2014.

Harder, H.: The role of magnesium in the formation of smectite mineral, Chem. Geol., 10, 31-39, 1972.

Hilton, R. G.: Climate regulates the erosional carbon export from the terrestrial biosphere, Geomorphology, 277, 118-132, 2017.

Jobbagy, E. G. and Jackson R. B.: The distribution of soil nutrients with depth: Global patterns and the imprint of plants, Biogeochemistry, 53, 51-77, 2001.
Johnson, C. M., Beard, B. L., and Albarède, F.: Geochemistry of Non-Traditional Stable Isotopes, Rev. Mineral. Geochem., 55, 1454, 2004.

Johnson, C. E., Siccama, T. G., Denny, E. G., Koppers, M. M., and Vogt, D. J.: In situ decomposition of northern hardwood tree boles: decay rates and nutrient dynamics in wood and bark, Can. J. Forest Res., 44, 1515-1524, 2014.

Johnson, D. W., Hunsaker, C. T., Glass, D. W., Rau, B. M., and Roath, B. A.: Carbon and nutrient contents in soils from the Kings River Experimental Watersheds, Sierra Nevada Mountains, California, Geoderma, 160, 490-502, 2011.

Jongmans, A. G., van Breemen, N., Lundström, U., van Hees, P. A. W., Finlay, R. D., Srinivasan, M., Unestam, T., Giesler, R., Melkerud, P.-A., and Olsson, M.: Rock-eating fungi, Nature, 389, 682-683, 1997.

Kirchner, J. W., Finkel, R. C., Riebe, C. S., Granger, D. E., Clayton, J. L., King, J. G., and Megahan, W. F.: Mountain erosion over $10 \mathrm{yr}, 10$ k.y., and 10 m.y. time scales, Geology, 29, 591594, 2001.

Klemmedson, J. O.: Decomposition and nutrient release from mixtures of Gambel oak and ponderosa pine leaf litter, Forest Ecol. Manag., 47, 349-361, 1992.

Klemmedson, J. O., Meier, C. E., and Campbell, R. E.: Litter fall transfers of dry matter and nutrients in ponderosa pine stands, Can. J. Forest Res., 20, 1105-1115, 1990.

Laclau, P.: Biomass and carbon sequestration of ponderosa pine plantations and native cypress forests in northwest Patagonia, Forest Ecol. Manag., 180, 317-333, 2003.

Landeweert, R., Hoffland, E., Finlay, R. D., Kuyper, T. W., and van Breemen, N.: Linking plants to rocks: ectomycorrhizal fungi mobilize nutrients from minerals, Trends Ecol. Evol., 16, 248-254, 2001.

Lang, F., Bauhus, J., Frossard, E., George, E., Kaiser, K., Kaupenjohann, M., Krüger, J., Matzner, E., Polle, A., Prietzel, J., Rennenberg, H., and Wellbrock, N.: Phosphorus in forest ecosystems: New insights from an ecosystem nutrition perspective, J. Plant Nutr. Soil Sc., 179, 129-135, 2016.

Law, B. E., Ryan, M. G., and Anthoni, P. M.: Seasonal and annual respiration of a ponderosa pine ecosystem, Glob. Change Biol. 5, 169-182, 1999.

Lucas, Y.: The role of plants in controlling rates and products of weathering: Importance of biological pumping, Annu. Rev. Earth Pl. Sc., 29, 135-163, 2001.

Ma, L., Teng, F. Z., Jin, L., Ke, S., Yang, W., Gu, H. O., and Brantley, S. L.: Magnesium isotope fractionation during shale weathering in the Shale Hills Critical Zone Observatory: Accumulation of light $\mathrm{Mg}$ isotopes in soils by clay mineral transformation, Chem. Geol., 397, 37-50, 2015.

Marschner, H: Marschner's mineral nutrition of higher plants, Academic press, available at: https://www.elsevier.com/books/ marschners-mineral-nutrition-of-higher-plants/marschner/ 978-0-12-384905-2 (last access: 22 June 2017), 2011.

Mavromatis, V., Prokushkin, A. S., Pokrovsky, O. S., Viers, J., and Korets, M. A.: Magnesium isotopes in permafrost-dominated Central Siberian larch forest watersheds, Geochim. Cosmochim. Ac., 147, 76-89, 2014.

McCorkle, E. M., Berhe, A. A., Hunsaker, C. T., Johnson, D. W., McFarlane, K. J., Fogel, M. L., and Hart, S. C.: Tracing the source of soil organic matter eroded from temperate forest catch- 
ments using carbon and nitrogen isotopes, Chem. Geol., 44, 172$184,2016$.

Dai, M.-N., Bao, Z.-A., Chen, K.-Y., and Yuan, H.-L.: In situ Analysis of Mg Isotopic Compositions of Basalt Glasses by Femtosecond Laser Ablation Multi-collector Inductively Coupled Plasma Mass Spectrometry, Chinese J. Anal. Chem., 44, 173-178, 2016.

Moulton, K. L., West, J., and Berner, R. A.: Solute flux and mineral mass balance approaches to the quantification of plant effects on silicate weathering, Am. J. Sci., 300, 539-570, 2000.

Oeser, M., Wexer, S., Horn, I., and Schuth, S.: High-Precision Fe and $\mathrm{Mg}$ Isotope Ratios of Silicate Reference Glasses Determined In Situ by Femtosecond LA-MC-ICP-MS and by Solution Nebulisation MC-ICP-MS, Geostand. Geoanal. Res., 38, 311-328, 2014.

Opfergelt, S., Burton, K. W., Georg, R. B., West, A. J., Guicharnaud, R. A., Sigfusson, B., Siebert, C., Gislason, S. R., and Halliday, A. N.: Magnesium retention on the soil exchange complex controlling $\mathrm{Mg}$ isotope variations in soils, soil solutions and vegetation in volcanic soils, Iceland, Geochim. Cosmochim. Ac., 125, 110-130, 2014.

Pearson, J. A., Knight, D. H., and Fahey, T. J.: Biomass and nutrient accumulation during stand development in Wyoming lodgepole pine forests, Ecology, 68, 1966-1973, 1987.

Pogge von Strandmann, P. A. E., Elliott, T., Marschall, H. R., Coath, C., Lai, Y.-J., Jeffcoate, A. B., and Ionov, D. A.: Variations of Li and $\mathrm{Mg}$ isotope ratios in bulk chondrites and mantle xenoliths, Geochim. Cosmochim. Ac., 75, 5247-5268, 2011.

Porder, S., Vitousek, P. M., Chadwick, O. A., Chamberlain, C. P., and Hilley, G. E.: Uplift, Erosion and Phosphorus Limitation in Terrestrial Ecosystems, Ecosystems, 10, 158-170, 2007.

Riebe, C. S. and Granger, D. E.: Quantifying effects of deep and near-surface chemical erosion on cosmogenic nuclides in soils, saprolite, and sediment, Earth Surf. Proc. Land., 38, 523-533, 2013.

Röderstein, M., Hertel, D., and Leuschner, C.: Above-and belowground litter production in three tropical montane forests in southern Ecuador, J. Trop. Ecol., 21, 483-492, 2005.

Roering, J. J., Marshall, J., Booth, A. M., Mort, M., and Jin, Q. S.: Evidence for biotic controls on topography and soil production, Earth Planet. Sc. Lett., 298, 183-190, 2010.

Ryu, J.-S., Vigier, N., Decarreau, A., Lee, S.-W., Le, K.-S., Song, $\mathrm{H}$., and Petit, S.: Experimental investigation of Mg isotope fractionation during mineral dissolution and clay formation, Chem. Geol., 445, 135-145, 2016.
Schaller, M., von Blanckenburg, F., Hovius, N., and Kubik, P.: Large-scale erosion rates from in situ-produced cosmogenic nuclides in European river sediments, Earth Planet. Sc. Lett., 188, 441-458, 2001.

Schuessler, J. A. and von Blanckenburg, F.: Testing the limits of micro-scale analyses of Si stable isotopes by femtosecond laser ablation multicollector inductively coupled plasma mass spectrometry with application to rock weathering, Spectrochim. Acta B, 98, 1-18, 2014.

Schuessler, J. A., Kämpf, H., Koch, U., and Alawi, M.: Earthquake impact on iron isotope signatures recorded in mineral spring water, J. Geophys. Res.-Sol. Ea., 121, 8548-8568, https://doi.org/10.1002/2016JB013408, 2016.

Sommer, M., Jochheim, H., Höhn, A., Breuer, J., Zagorski, Z., Busse, J., Barkusky, D., Meier, K., Puppe, D., Wanner, M., and Kaczorek, D.: Si cycling in a forest biogeosystem - the importance of transient state biogenic Si pools, Biogeosciences, 10, 4991-5007, https://doi.org/10.5194/bg-10-4991-2013, 2013.

Stone, E. L. and Kalisz, P. J.: On the maximum extent of tree roots, Forest Ecol. Manag., 46, 59-102, 1991.

Tipper, E. T., Lemarchand, E., Hindshaw, R. S., Reynolds, B. C., and Bourdon, B.: Seasonal sensitivity of weathering processes: hints from magnesium isotopes in a glacial stream, Chem. Geol., 312-313, 80-92, 2012.

Uhlig, D., Schuessler, J. A., Bouchez, J., Dixon, J. L., and von Blanckenburg, F.: Supplementary dataset for: Quantifying nutrient uptake as driver of rock weathering in forest ecosystems by magnesium stable isotopes, GFZ Data Services, https://doi.org/10.5880/GFZ.3.3.2017.001, 2017.

Vitousek, P. M. and Farington, H.: Nutrient limitation and soil development: Experimental test of a biogeochemical theory, Biogeochemistry, 37, 63-75, 1997.

West, A. J., Galy, A., and Bickle, M. J.: Tectonic and climatic controls on silicate weathering, Earth Planet. Sc. Lett., 235, $211-$ 228, 2005.

Wimpenny, J., Colla, C. A., Yin, Q.-Z., Rustad, J. R., and Casey, W. $\mathrm{H}$.: Investigating the behavior of $\mathrm{Mg}$ isotopes during the formation of clay minerals, Geochim. Cosmochim. Ac., 128, 178-194, 2014. 